\title{
OS RECURSOS HÍDRICOS SUBTERRÂNEOS E AS NOVAS EXIGÊNCIAS AMBIENTAIS
}

\author{
Ricardo César Aoki HIRATA
}

\author{
RESUMO
}

A gestão das águas subterrâneas se faz pela administração do recurso em aspectos de qualidade e quantidade. $\mathrm{O}$ primeiro associado à proteção dos aqüíferos contra a contaminação antrópica e o outro, à proteção contra a exploração excessiva, que exaure o recurso. Este trabalho apresenta as bases técnicas para compor um programa integrado de proteção dos recursos hídricos subterrâneos, definindo estratégias e prioridades de ação por parte de órgãos estatais e privados. É discutida, também, a relação da hidrogeologia com outras áreas das ciências da Terra, no planejamento físico-territorial.

A avaliação e administração do recurso hídrico subterrâneo deve se iniciar pelo reconhecimento dos aqüíferos, através de cadastros de poços já perfurados. Estas informações, associadas aos mapas geológicos e aos dados da hidrologia superficial, permitirão construir mapas hidrogeológicos e avaliar os recursos e seus usuários. Nas áreas de maior demanda e/ou densidade de obras de captação será necessária uma atenção maior dos órgãos gestores do recurso. Em tais locais a perfuração e exploração de poços deverão ser precedidas por estudos e autorizações de uso, volume e tempo de bombeamento permitidos. Ao contrário, em áreas onde a possibilidade de conflitos é menor, muitas vezes somente será necessária a notificação da perfuração da obra.

Um programa de proteção da qualidade deverá contemplar, de forma integrada, duas linhas de ação: uma voltada à obra de captação, como estabelecimento de perímetros de proteção de poços, e outra voltada ao aqüífero, definindo áreas de maior e menor susceptibilidade de contaminação por eventos antrópicos, através de cartografias de vulnerabilidade. Para a implementação de ações corretivas e de programas de monitoração regulares dos aqüíferos, é necessária a identificação de áreas de maior risco de contaminação. Estas poderão ser estabelecidas a partir do cruzamento da cartografia de vulnerabilidade com a carga contaminante potencial. Os maiores riscos permitirão definir prioridades de ação dos órgãos competentes.

\section{ABSTRACT}

Management of groundwater is made effective by considering quality and quantity. The former is associated with aquifer protection against anthropic contamination, the latter with the protection against excessive exploitation. The present paper presents technical bases to an integrated program of protection of grondwater resources, defining strategies and action priorities to be taken by governmental and private agencies. The relationship between hydrology and other areas of the Geosciences in physico-territorial planning is also discussed.

The evaluation and administration of a groundwater resource should start with the recognition of the aquifers, from well records. This information associated with geological maps and superficial hydrological data, will allow the constrution of hydrological maps and evaluation of the resources and their uses. In areas of greater demand and/or density of pumping wells, closer attention from the resource management agencies is necessary. In such localities, well perforation and exploitation must be preceded by studies and requests for permits for volume, usage and duration of pumping. On the other hand, areas where the probability of conflict is lower, a simple notification of perfuration is all that is needed in most cases.

A program of quality protection in integrated form must contemplate two lines of action: one directed to the captation works, for the establishment of well protection areas and the other, directed to the aquifer, defining areas of major and minor contamination susceptibility by anthropic actions, through vulnerability cartography. To implement correction actions and regular aquifer monitoring programs, it is necessary to identify areas of major contamination risk. These can be established by crossing information from the vulnerability cartography with potential contaminant load. Greater risks will allow priority actions from the agencies in question. 


\section{A IMPORTÂNCIA DAS ÁGUAS SUBTERRÂNEAS}

A importância das águas subterrâneas para o abastecimento público e privado é inquestionável. No continente latino-americano o uso do recurso atende a mais de 140 milhões de pessoas (1987). Pelo menos duas grandes conurbações no continente, Cidade do México e Grande Lima, são abastecidas em grandes proporções por águas subterrâneas. No caso da Cidade do México, um volume de $3.200 \mathrm{Ml} / \mathrm{d}$ ( $94 \%$ do suprimento total em 1982) é originado pela captação dos 1.100 poços tubulares do Vale do México e 230 poços do Vale de Lerma. No caso da Grande Lima, as águas de uso doméstico e municipal têm origem em 320 poços tubulares, que produzem quantidades superiores a $650 \mathrm{Ml} / \mathrm{d}$. Em outras grandes cidades do continente, Buenos Aires (360Ml/d) e Santiago do Chile (950Ml/d), as águas subterrâneas suprem a maior parte do abastecimento público e privado (FOSTER et al., 1987).

$\mathrm{O}$ relativo baixo custo e, na maioria dos casos, a excelente qualidade natural das águas subterrâneas têm sido suficientes para justificar sua exploração como fonte de água potável, mesmo em muitas regiões de clima tropical úmido. No Brasil, estima-se a existência de 200.000 poços tubulares ativos, além de milhões de poços rasos escavados, que fornecem água para diversos fins, sobretudo o abastecimento urbano, permitindo suprir as necessidades de $51 \%$ da população (REBOUÇAS \& MENEZES, 1988). No Estado de São Paulo, as águas subterrâneas chegam de forma total ou complementar para $61 \%$ dos núcleos urbanos, somando um atendimento de $13 \%$ da população.

A utilização do recurso hídrico subterrâneo tende a aumentar nos próximos anos, tanto em decorrência da concentração demográfica e da expansão econômica, como por suas vantagens com relação às águas superficiais. Todavia, a situação atual de exploração é marcada por uma visão imediatista de uso do recurso, prevalecendo descontrole e falta de mecanismos legais e normativos. Nessas condições os aqüíferos em diferentes partes do território brasileiro estão sujeitos aos impactos da extração descontrolada por poços e à ocupação indisciplinada do uso do solo, que põem em risco a qualidade natural das águas.

\section{PROBLEMAS RELACIONADOS À PROTEÇÃO DAS ÁGUAS SUBTERRÂNEAS}

A proteção das águas subterrâneas envolve dois aspectos complementares: problemas associados à superexploração, ou seja, a retirada sem controle e danosa de água, que faz com que a extração seja superior à recarga em um certo aqüífero, ou parte dele; e à contaminação do recurso hídrico subterrâneo, que leva, muitas vezes, à degradação irreversível da qualidade das águas do aqüífero.

Qualquer extração de águas subterrâneas causa certo descenso nos níveis freáticos e piezométricos dos aqüíferos e um certo grau de interferência entre poços ou mananciais próximos. Gerir o recurso significa propor políticas que permitam que estas interferências e descensos nos níveis sejam toleráveis e previnam uma redução forte nos rendimentos individuais dos poços ou mesmo rebaixamentos regionais (FOSTER et al., 1991), garantindo que o aqüífero seja uma fonte segura e confiável de abastecimento de água potável, com otimização de investimentos.

A contaminação das águas subterrâneas por atividades antrópicas tem causado o abandono de muitos poços ou perda de áreas importantes do manancial. A limpeza de aqüíferos é um procedimento caro, demorado e ainda com muitas restrições técnicas. A forte degradação das águas de um aqüífero continua a ser considerada como um fato irreversível, sobretudo em economias do Terceiro Mundo, devido aos custos que ultrapassam dezenas de milhões de dólares.

\subsection{A superexploração dos aqüíferos: problemas associados}

A exploração excessiva de aqüíferos, além dos limites tecnicamente seguros, é prática comum em muitas cidades de médio e grande porte no continente latino-americano. Em um número ainda maior de casos, a falta de estudos detalhados não permite avaliar se a exploração do recurso hídrico subterrâneo está sendo levada de forma a exaurir o aqüífero. A perfuração indiscriminada, com extrações sem controle de um número excessivo de poços, e a dificuldade no cálculo de recarga não possibilitam uma indicação da vazão global segura para um dado aqüífero.

Em algumas situações, o desequilíbrio causado pela superexploração poderá ser momentâneo e controlado, não oferecendo problemas a longo prazo ao aqǘfero. Muitas práticas, quando analisadas tecnicamente e aceitáveis do ponto de vista econômico, são plenamente justificáveis. Entretanto, quando não-planejadas, poderão criar problemas associados à:

(1) diminuição no rendimento de poços próximos e/ou grandes aumentos nos custos de bombeamento;

(2) indução de contaminação por intrusão salina, pelo desequilíbrio hidráulico entre a cunha de água salgada e doce;

(3) infiltração induzida de águas de baixa qualidade de aqüíferos mais superficiais ou de drenagens contaminadas; 
(4) redução dos níveis de corpos de águas superficiais;

(5) estabilidade geotécnica do terreno, pela drenagem de aqüíferos.

Poucos são os casos de descensos de níveis de água em aqüíferos bem documentados no Brasil. CAMPOS (1988), analisando os mapas hidrogeológicos na Grande São Paulo (Aqüífero São Paulo), verificou ao longo de 20 anos rebaixamentos da ordem de 20 a $40 \mathrm{~m}$, em algumas regiões centrais da cidade de São Paulo. Isto é atribuído ao intenso bombeamento e à diminuição da recarga pela impermeabilização do terreno pelas construções. Tal situação tem induzido mudanças de fluxo no aqüífero que poderá levar águas de pior qualidade a migrarem dos córregos e rios para o aqüífero. A partir de simulações matemáticas, MONTENEGRO \& RIGHETTO (1990) verificaram que o Aqüífero Botucatu, na cidade de Ribeirão Preto (SP), chegará em 1996, sob hipótese de incremento de demanda de $5 \%$ ao ano, a descensos da ordem de $60 \mathrm{~m}$, comparativamente aos valores simulados em 1983, em uma grande extensão do aqüífero, que compreende a cidade.

Situações mais dramáticas são experimentadas em algumas cidades do continente. Em Lima (Peru), são registrados rebaixamentos que chegam a atingir $4 \mathrm{~m}$ ao ano, em porções localizadas do aqüífero. Acompanhamentos periódicos no rendimento dos poços têm mostrado que, entre 1975 e 1985, o gasto por poço elevou-se de $0,7 \mathrm{a} 0,9 \mathrm{~kW} / \mathrm{m}^{3}$, com queda na vazão média de 32 a 25 1/s.

Problemas associados à intrusão salina têm sido verificados em decorrência da extração de um volume de água superior à descarga natural do aqüífero ao mar, ocasionando um desequilíbrio hidráulico. MENEZES \& ARAÚJO (1988), estudando a praia de Abreulândia (CE), indicaram através de análises físico-químicas, balanços de recarga e extração, o avanço da cunha salina, decorrente da exploração de poços próximos à linha de costa.

\subsection{As conseqüências da contaminação das águas subterrâneas}

A preocupação a respeito da poluição das águas subterrâneas é recente e bastante restrita em nosso país. O usuário do recurso subterrâneo, particular ou governamental, ainda desconhece a sua importância e ignora as graves conseqüências de sua contaminação. Esta atitude generalizada de subestimação dos riscos de poluição de aqüíferos leva à falta de políticas e de ações voltadas à proteção das águas subterrâneas.

A degradação da qualidade das águas subterrâneas tem motivado uma atenção maior, sobretudo nas proximidades de grandes centros urbanos, devido aos seguintes fatores:
(1) aumento nas práticas de disposição dos efluentes domésticos e industriais sobre os solos, em larga escala, como resultado dos elevados custos de tratamento ou eliminação dos resíduos líquidos;

(2) aumento e diversificação de produtos químicos, potencialmente contaminantes das águas subterrâneas, sobretudo nas três últimas décadas;

(3) uso crescente de fertilizantes e pesticidas na agricultura;

(4) dificuldade e impraticabilidade técnica e econômica de restauração de aqüíferos contaminados;

(5) efeitos potencialmente nocivos à saúde, associados à poluição de captações de águas subterrâneas, acarretando concentrações baixas, mas persistentes, de contaminantes de toxicologia pouco conhecida;

(6) impraticabilidade de um tratamento adequado para remover contaminantes de um grande número de fontes pontuais de captação (poços).

A falta de medidas adequadas de controle da contaminação das águas subterrâneas pode ocasionar sérias conseqüências, entre elas (FOSTER et al., 1991):

(1) abandono do poço e perda de investimentos aplicados no desenvolvimento dos recursos hídricos;

(2) necessidade de introduzir custosos processos de tratamento para as captações de água subterrânea, factíveis quando existirem tecnologias apropriadas de forma operacional e econômica;

(3) custosos programas de longo prazo para reabilitar os aqüíferos. Estudos têm mostrado, entretanto, que a completa descontaminação possui limitações técnicas, ainda não completamente resolvidas, o que pode ocasionar a perda do recurso hídrico.

Várias são as atividades do homem que podem gerar uma carga contaminante no subsolo. $\mathrm{O}$ quadro 1 apresenta um resumo dessas atividades assinalando aquelas de maior probabilidade de ocorrência no continente latino-americano.

Numa análise de atividades é importante reconhecer quais fontes são de emissão pontual, normalmente mais fáceis de identificar, e quais são as fontes dispersas. Da mesma forma, devem ser distinguidas atividades onde a geração de carga é parte integral do sistema, daquelas onde estão envolvidos componentes acidentais e incidentais, sobretudo considerando-se a prevenção e controle de contaminação.

Sistemas de saneamento "in situ" - Em grandes cidades, a principal preocupação está nas áreas urbanizadas sem rede de esgoto, onde o lançamento de águas servidas se dá pela infiltração através de fossas e tanques sépticos ou negros. 
QUADRO 1 - ATIVIDADES ANTRÓPICAS, MAIS COMUNS NA AMÉRICA LATINA, POTENCIALMENTE GERADORAS DE CARGA CONTAMINANTE AO AQÜÍFERO (FOSTER \& HIRATA, 1988)

\begin{tabular}{|c|c|c|c|c|}
\hline \multirow{2}{*}{ ATIVIDADE } & \multicolumn{4}{|c|}{ CARACTERÍSTICA DA CARGA CONTAMINANTE } \\
\hline & distribuição & principal contaminante & $\begin{array}{l}\text { sobrecarga } \\
\text { hidráulica }\end{array}$ & $\begin{array}{c}\text { ausência de } \\
\text { camada de solo }\end{array}$ \\
\hline \multicolumn{5}{|l|}{ URBANA } \\
\hline $\begin{array}{l}\text { Saneamento "in situ" } \\
\text { Vazamento de esgotos (a) } \\
\text { Lagoas de oxidação (a) } \\
\text { Aplicação de águas residuais em superfície (a) } \\
\text { Rios e canais de recepção (a) } \\
\text { Lixiviado de lixões/aterros sanitários } \\
\text { Tanques de combustível } \\
\text { Drenos de rodovias }\end{array}$ & $\begin{array}{l}u / r \text { P-D } \\
u \text { P-L } \\
\text { u/r P } \\
\text { u/r P-D } \\
\text { u/r P-L } \\
\text { u/r P } \\
\text { u/r P-D } \\
\text { u/r P-D }\end{array}$ & $\begin{array}{l}\mathrm{n} \text { f o } \\
\text { of } \mathrm{n} \\
\text { of } \mathrm{n} \\
\mathrm{n} \text { s of } \\
\text { n of } \\
\text { o s h } \\
\text { o } \\
\text { s o }\end{array}$ & $\begin{array}{l}+ \\
+ \\
++ \\
+ \\
++ \\
+\end{array}$ & $\begin{array}{l}\bullet \\
\bullet \\
\bullet \\
\bullet \\
\bullet \\
\bullet\end{array}$ \\
\hline \multicolumn{5}{|l|}{ INDÚSTRIA } \\
\hline $\begin{array}{l}\text { Vazamento de tanques/tubos (b) } \\
\text { Derramamento acidental } \\
\text { Lagoas de efluentes } \\
\text { Lançamento de efluentes em superfície } \\
\text { Canais e rios receptores } \\
\text { Lixiviado de resíduos sólidos } \\
\text { Drenos de pátios } \\
\text { Material em suspensão e gases }\end{array}$ & $\begin{array}{ll}u & P-D \\
u & P-D \\
u & P \\
u & P-D \\
u & P-L \\
u / r & P \\
u / r & P \\
u / r & D\end{array}$ & 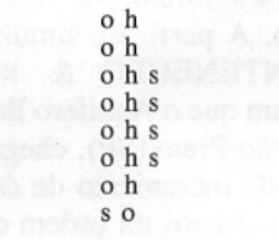 & $\begin{array}{l}+ \\
++ \\
+ \\
++ \\
++\end{array}$ & $\begin{array}{l}\bullet \\
\bullet \\
\bullet \\
\bullet \\
\bullet\end{array}$ \\
\hline $\begin{array}{l}\text { AGRÍCOLA (c) } \\
\text { a. Área de cultivo } \\
\text { - com agroquímicos } \\
\text { - e com irrigação } \\
\text { - com lodos/resíduos } \\
\text { - com irrigação de águas residuais }\end{array}$ & $\begin{array}{ll}\mathrm{r} & \mathrm{D} \\
\mathrm{r} & \mathrm{D} \\
\mathrm{r} & \mathrm{D} \\
\mathrm{r} & \mathrm{D}\end{array}$ & $\begin{array}{l}\mathrm{n} \circ \\
\mathrm{n} \circ \mathrm{o} \\
\mathrm{n} \text { o s } \\
\mathrm{n} \circ \mathrm{o} \mathrm{s} \mathrm{f}\end{array}$ & $\begin{array}{l}+ \\
+\end{array}$ & \\
\hline $\begin{array}{l}\text { b. Beneficiamento/criação de gado e animais } \\
\text { - lagoas de efluentes sem revestimento } \\
\text { - lançamento em superfície } \\
\text { - canais e rios receptores de efluentes }\end{array}$ & $\begin{array}{ll}\mathrm{r} & \mathrm{P} \\
\mathrm{r} & \mathrm{P}-\mathrm{D} \\
\mathrm{r} & \mathrm{P}-\mathrm{L}\end{array}$ & $\begin{array}{l}\mathrm{f} \circ \mathrm{n} \\
\mathrm{n} \text { s o f } \\
\text { o n f }\end{array}$ & $\begin{array}{l}++ \\
++\end{array}$ & • \\
\hline $\begin{array}{l}\text { EXTRAÇÃO MINERAL } \\
\text { Desmonte hidráulico } \\
\text { Descarga de água de drenagem } \\
\text { Lagoa de decantação } \\
\text { Lixiviado de resíduos sólidos }\end{array}$ & $\begin{array}{l}\text { r/u P-D } \\
\text { r/u P-D } \\
\text { r/u P } \\
\text { r/u P }\end{array}$ & $\begin{array}{l}\text { s h } \\
\text { h s } \\
\text { h s } \\
\text { s h }\end{array}$ & $\begin{array}{l}++ \\
+\end{array}$ & $\begin{array}{l}\bullet \\
\bullet \\
\bullet\end{array}$ \\
\hline \multicolumn{5}{|c|}{$\begin{array}{l}\text { (a) Pode incluir componentes industriais } \\
\text { (b) Pode também ocorrer em áreas não industriais } \\
\text { (c) Intensificação apresenta aumento no risco de contaminação }\end{array}$} \\
\hline \multicolumn{5}{|l|}{ P/L/D/R Pontual/linear/difuso/regional } \\
\hline $\begin{array}{ll}\text { n } & \text { Nutrientes } \\
\text { f } & \text { Patógenos fecais } \\
\text { o } & \text { Compostos orgânicos sintéticos e/ou carga } \\
\text { s } & \text { Salinidade } \\
\text { m } & \text { Metais pesados }\end{array}$ & ânica & & & \\
\hline
\end{tabular}

As instalações sépticas, quando bem construídas, manejadas e dispostas em locais adequados, são alternativas eficientes e de baixo custo. Quando carecendo de tais preceitos, esta prática poderá contaminar as águas subterrâneas com bactérias e vírus patogênicos, nitratos, elevadas concentrações de sais e algumas vezes solventes organo-sintéticos.

A poluição das fontes de água subterrânea por disposição de águas servidas no solo tem provocado numerosos casos de transmissão de doenças. A má construção, associada à proximidade entre lançamento e poço, sem uma boa caracte- rização hidrogeológica, tem sido a responsável direta por tais problemas.

Compostos de nitrogênio presentes nas excretas não representam, de imediato, perigo à qualidade das águas subterrâneas, mas podem causar problemas persistentes e de ocorrência ampla. Uma indicação desta situação é observada no seguinte exemplo: um núcleo urbano, com densidade populacional de $20 \mathrm{hab} / \mathrm{ha}$, gera uma descarga de $100 \mathrm{~kg} / \mathrm{ha} / \mathrm{a}$ que, se oxidada e lixiviada por uma infiltração de $100 \mathrm{~mm} / \mathrm{a}$, poderá resultar em uma recarga no aqüífero de concentrações da ordem de $100 \mathrm{mg} \mathrm{NO}_{3}-\mathrm{N} / \mathrm{I}$, quando as 
normas para água potável não devem exceder $10 \mathrm{mg} / 1$. Na prática, a proporção de nitrogênio que será lixiviada é desconhecida, uma vez que participam vários processos de diluição e oxidação-redução dos contaminantes. Em meios redutores, ao contrário da presença do nitrato, a ocorrência de amônio poderá gerar problemas de contaminação, quando os níveis d'água forem próximos da superfície (Figura 1).

Atividades industriais - Dadas as altas concentrações de produtos químicos que manuseiam e algumas práticas de disposição de efluentes e (a) variaçåo com l e u

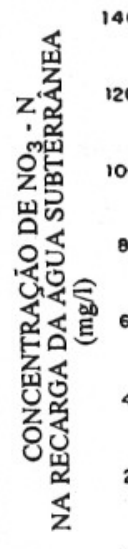

0

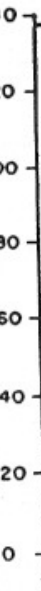

b) variaçăo com 1 e f

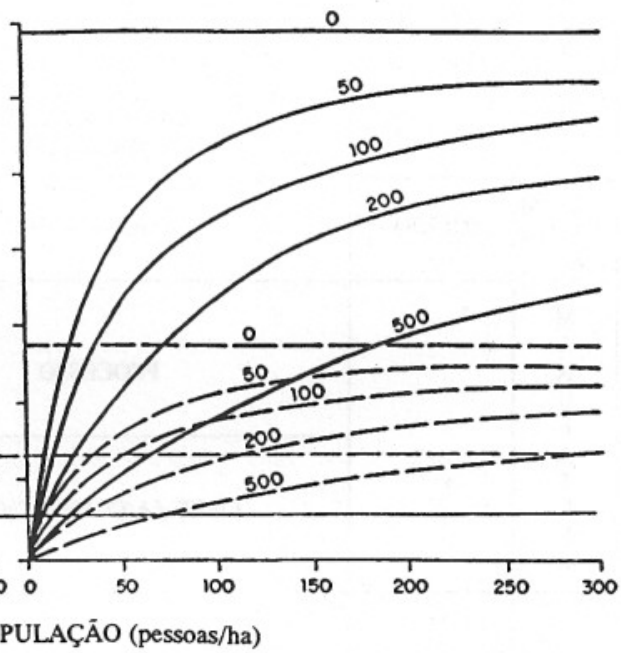

$\left.\begin{array}{l}--- \text { máximo } \\ \text { recomendado }\end{array}\right\} \begin{aligned} & \text { norma de água potável } \\ & \text { da OMS }\end{aligned}$

FIGURA 1 - Relação entre densidade populacional e contaminação das águas subterrâneas por nitratos (FOSTER \& HIRATA, 1989).

produtos que empregam, estas atividades são seguramente as que apresentam maiores riscos ambientais para as águas subterrâneas. Da mesma forma, devido à extrema diversidade de processos de manufatura, há maior dificuldade em se estimar a carga contaminante de forma simples e confiável (HIRATA \& FERREIRA, 1992).

Os principais problemas na definição da carga contaminante industrial estão associados à (FOSTER \& HIRATA, 1988):

(1) grande variedade de atividades industriais existentes;

(2) considerável variação no nível tecnológico de qualquer indústria;

(3) extrema e errática variação temporal nas concentrações de substâncias tóxicas nos efluentes;

(4) grande variação no uso e eficiência dos processos de tratamento para efluentes industriais e às incertezas sobre a efetividade na remoção de contaminantes potencialmente perigosos para as águas subterrâneas;

(5) falta de controle de qualidade e de análises químicas de efluentes e de resíduos diversos, incluindo metais pesados e compostos organo-sintéticos;

(6) falta de uma adequada informação publicada sobre as características de efluentes e resíduos de indústrias representativas, especialmente aquelas que funcionam em economias do Terceiro Mundo;

(7) grande variedade nos modos de manuseio e disposição de matérias-primas, resíduos sólidos e líquidos, incluindo a freqüente adoção de práticas clandestinas.

A estes problemas, agrega-se o fato de os órgãos de controle ambiental estarem mais preparados para analisar contaminações em águas superficiais do que em águas subterrâneas. A contaminação de aqüíferos é assunto relativamente novo e pouco conhecido. Esquemas de vigilância ambiental, controle e diagnósticos são, por esta razão, executados tecnicamente de forma incompleta ou incorreta. Normalmente os cadastros de indústrias controladas e monitoradas são estabelecidos com base nos lançamentos às águas superficiais e à atmosfera.

De maneira simplificada, uma atividade industrial poderá gerar cargas contaminantes importantes associadas à disposição de matériasprimas, aos processos de manufatura, aos resíduos industriais e aos processos de tratamento de resíduos (QUADRO 2).

Deve ser enfatizado que as maiores e mais sofisticadas indústrias não são as que, necessa- 
QUADRO 2 - CARACTERIZAÇÃO DA ATIVIDADE INDUSTRIAL COMO FONTE GERADORA DE CARGA CONTAMINANTE AO SUBSOLO (HIRATA \& FERREIRA, 1992)

\begin{tabular}{|c|c|c|c|}
\hline $\begin{array}{l}\mathrm{P} \\
\mathrm{R} \\
\mathrm{O} \\
\mathrm{C} \\
\mathrm{E} \\
\mathrm{S} \\
\mathrm{S} \\
\mathrm{O} \\
\mathrm{S} \\
\end{array}$ & $\begin{array}{ll}\mathrm{E} & \\
\mathrm{S} & \mathrm{R} \\
\mathrm{T} & \mathrm{E} \\
\mathrm{A} & \mathrm{S} \\
\mathrm{D} & \mathrm{I} \\
\mathrm{O} & \mathrm{D} \\
& \mathrm{U} \\
\mathrm{D} & \mathrm{O} \\
\mathrm{O} & \end{array}$ & FORMA DE DISPOSIÇÃO & EVENTO CONTAMINADOR \\
\hline & \multirow{2}{*}{ FLUIDO } & \multirow{2}{*}{$\begin{array}{l}\text { TANQUES (PRINCIPALMENTE } \\
\text { ENTERRADOS) }\end{array}$} & VAZAMENTO DE TANQUES E DUTOS \\
\hline $\begin{array}{ll}T & R \\
S & I\end{array}$ & & & ACIDENTE NO TRANSPORTE/CARGA/DESCARGA \\
\hline $\begin{array}{ll}\mathrm{R} & \mathrm{M} \\
\mathrm{N}\end{array}$ & \multirow{2}{*}{ SóLIDO } & \multirow{2}{*}{ PÁTIOS/GALPÃO } & INFILTRAÇÃO NO SOLO (UMIDADE) \\
\hline & & & INFILTRAÇÃO POR CARREAMENTO DA CHUVA \\
\hline \multirow{2}{*}{$\begin{array}{l}\mathrm{M} \\
\mathrm{A} \\
\mathrm{N} \\
\mathrm{U} \\
\mathrm{F} \\
\mathrm{A} \\
\mathrm{T} \\
\mathrm{U} \\
\mathrm{R} \\
\mathrm{A}\end{array}$} & & PROCESSO & VAZAMENTO DE MÁQUINAS E DUTOS \\
\hline & & LIMPEZA/CONSERVAÇÃO & $\begin{array}{l}\text { LíQUIDOS DE LIMPEZA E LAVAGEM DE } \\
\text { PEÇAS E MÁQUINAS }\end{array}$ \\
\hline \multirow{7}{*}{$\begin{array}{l}\mathrm{I} \\
\mathrm{N} \\
\mathrm{D} \\
\mathrm{U} \\
\mathrm{S} \\
\mathrm{T} \\
\mathrm{R} \\
\mathrm{I} \\
\mathrm{A} \\
\mathrm{I} \\
\mathrm{S}\end{array}$} & $\begin{array}{c}\mathrm{G} \\
\mathrm{A} \\
\mathrm{S} \\
\mathrm{E} \\
\mathrm{S} \\
\text { (inclusive } \\
\text { incineração) } \\
\end{array}$ & LANÇAMENTO À ATMOSFERA & $\begin{array}{l}\text { EXAUSTÃO E PRECIPITAÇÃO DOS VAPORES COM } \\
\text { AS CHUVAS E INFILTRAÇÃO NO SOLO }\end{array}$ \\
\hline & \multirow{5}{*}{$\begin{array}{l}\mathrm{L} \\
\mathrm{I} \\
\mathrm{Q} \\
\mathrm{U} \\
\mathrm{I} \\
\mathrm{D} \\
\mathrm{O} \\
\mathrm{S}\end{array}$} & LAGOAS E EFLUENTES & \multirow{4}{*}{$\begin{array}{l}\text { CONEXÃO HIDRÁULICA IMPORTANTE } \\
\text { COM AQÜÍFERO }\end{array}$} \\
\hline & & CORPOS DE ÁGUAS SUPERFICIAL & \\
\hline & & INJEÇÃ̃O PROFUNDA (poço) & \\
\hline & & NO SOLO (infiltração) & \\
\hline & & OCEÂNICA & NÃO DEFINIDO CONTAMINAÇÃO \\
\hline & $\begin{array}{l}\text { S } \\
\text { Ó } \\
\text { L } \\
\text { I } \\
\text { D } \\
\text { O } \\
\text { S }\end{array}$ & ATERROS & INFILTRAÇÃO DE CHORUME \\
\hline \multirow{2}{*}{ 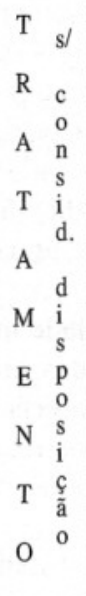 } & \multirow{2}{*}{$\begin{array}{l}\text { S } \\
\text { O } \\
\text { L } \\
\text { I } \\
\text { D } \\
\text { O } \\
\bar{L} \\
\text { L } \\
\text { I } \\
\text { Q } \\
\text { U } \\
\text { I } \\
\text { D } \\
\text { O } \\
\text { G } \\
\text { A } \\
\text { S } \\
\text { O } \\
\text { S } \\
\text { O }\end{array}$} & $\begin{array}{l}\text { PROVISÓRIA EM RECIPIENTES OU EM } \\
\text { GALPÕES/PÁTIOS À ESPERA DE } \\
\text { TRATAMENTO OU DESTINAÇÃO FINAL } \\
\text { (INCLUSIVE DE LODOS DE } \\
\text { TRATAMENTO) }\end{array}$ & $\begin{array}{l}\text { VAZAMENTO/ACIDENTE TRANSPORTE/ } \\
\text { CARGA/DESCARGA }\end{array}$ \\
\hline & & $\begin{array}{c}\text { DISPOSIÇÃO INCORRETA DE } \\
\text { LODOS DO SISTEMA DE TRATAMENTO }\end{array}$ & INFILTRAÇÃO NO SOLO \\
\hline
\end{tabular}


riamente, apresentam os mais altos riscos de poluição das águas subterrâneas. Isto porque, com freqüência, estas atividades utilizam-se de processos mais eficientes e melhor controle na disposição e manipulação de produtos e resíduos perigosos. Entretanto, as indústrias menores possuem uma maior distribuição geográfica e são mais numerosas. Normalmente, manejam consideráveis quantidades de produtos tóxicos e adotam práticas não muito recomendadas.

Indústrias com sistemas de tratamento não estão isentas de problemas de contaminar as águas subterrâneas, já que o armazenamento e transporte de substâncias perigosas podem gerar cargas contaminantes importantes, em caso de acidente.

Resíduos sólidos - A disposição de resíduos, de origem doméstica ou industrial, tem sido causadora de inúmeros incidentes de contaminação das águas subterrâneas em nosso país (CASTRO NETO et al., 1984; GUIGUER, 1987; BERNARDES et al., 1991; HIRATA \& BASTOS, 1992). Os mais sérios riscos ocorrem quando o empreendimento é praticado sem controle e onde a disposição de resíduos sólidos e, principalmente, líquidos perigosos é colocada em locais não apropriados, em áreas geologicamente vulneráveis.

Em muitos casos, resíduos industriais perigosos, que podem conter metais pesados e solventes orgânicos, são colocados em áreas destinadas aos resíduos domésticos. A disposição clandestina de substâncias tóxicas é comum em muitas regiões, dificultando uma avaliação precisa dos perigos para o aqǘf́ero, associada à incerteza na qualidade do chorume lixiviado.

A construção de aterros de resíduos sólidos tem que obedecer normas mínimas (ABNT). A obra deverá ser bem localizada em relação aos aqüíferos existentes. Estudos hidrogeológicos prévios serão necessários e, quando da construção, deverá ser exigida uma camada impermeável inferior de argila de 0,6 a $1,5 \mathrm{~m}$ de espessura e um recobrimento diário de 0,1 a $0,3 \mathrm{~m}$ de material compactado. Algumas vezes será necessária a colocação de camadas de material sintético (liner), de grande resistência mecânica e química, para garantir a completa vedação hidráulica do empreendimento. Naturalmente, os estratos da zona não-saturada deverão ser de material de baixa permeabilidade. Um cuidado especial precisará ser dado aos resíduos recebidos, especificando origem e composição mínima. Drenos superficiais serão necessários para diminuir o ingresso de águas de chuva por escorrimento superficial, no núcleo do aterro.

Pode ser aceitável a construção de aterros que recebam materiais de origem doméstica em áreas mais permeáveis, sempre e quando o nível freático estiver a grande profundidade. Também deveriam ser tomadas precauções contra a geração de grandes quantidades de lixiviado com carga orgânica abundante. Entretanto, sempre existirá o risco da deposição de materiais perigosos clandestinamente (FOSTER et al., 1991).

Adicionalmente, para qualquer empreendimento poderá ser exigido um sistema de monitoração da qualidade das águas subterrâneas, através de poços especialmente construídos.

Atividades agrícolas - $\mathrm{O}$ comportamento pouco conhecido de pesticidas em subsuperfície, associado às baixas concentrações e à ampla distribuição em suas aplicações, faz da atividade agrícola uma das mais difíceis de ser avaliada. O número de trabalhos desenvolvidos é insuficiente para permitir uma caracterização satisfatória de impactos causados por pesticidas associados ao manejo agrícola. É certo que evidências de contaminação de aqüíferos pela atividade agrícola remonta à década de 70 , mas estava restrito ao uso de fertilizantes, sobretudo compostos nitrogenados. Com as facilidades analíticas das instituições de controle ambiental, iniciou-se uma ampla monitoração das águas subterrâneas em muitos países do Primeiro Mundo. Os resultados significativos de tais varreduras mostraram que os agrotóxicos, tidos, até a década passada, como causadores de baixo impacto sobre os aqüíferos, merecem estudos mais detalhados.

O uso de fertilizantes inorgânicos está se expandindo de forma bastante rápida em muitos países latino-americanos, numa tentativa de aumentar a produtividade agrícola. Como conseqüência desta prática, muitos solos, anteriormente pobres em nutrientes, passaram a conter excesso intermitente de sais, de compostos nitrogenados e de outros produtos que, mobilizados pelo excesso de água infiltrada, podem chegar a contaminar os aqüíferos.

Um extenso programa de monitoração, definido nos EUA na última década, mostrou que mais de 70 pesticidas tinham sido detectados nas águas subterrâneas, sendo resultado do uso agrícola de tais produtos. Aldicarb, alaclor e atrazinas, juntamente com fumigantes do solo do tipo EDB, DCP e DBCP e herbicidas como simazina e cianazina, foram os agrotóxicos mais freqüentes (RITTER, 1990).

Pesquisas analisando o uso de pesticidas e nutrientes, manejo do solo e culturas, além de características mínimas naturais do solo agrícola, definiram perigos potenciais de geração de cargas que podem contaminar o subsolo. Estes trabalhos identificaram os inseticidas organofosforados sistêmicos (metamidofós, monocrotofós, vamidotion e acetato) associados às culturas anuais (algodão, soja, feijão e hortaliças), além do aldicarb nas plantações de banana, café e ba- 
tata, como os de maior perigo. Entre os herbicidas, foram identificados o dalapon, simazina, bentazon e 2,4 $\mathrm{D}$ aplicados nas culturas de cana, café, fruticultura (citros) e anuais. $O$ fosetil caracterizou-se como o produto de maior perigo entre os fungicidas (RODRIGUES et al., 1992; HIRATA \& BASTOS, 1992).

Os fatores que determinam a taxa de lixiviação de compostos nitrogenados, sais e pesticidas dos solos cultivados são complexos. Os contro- les principais são enumerados na figura 2 . Neste contexto é mais lógico considerar o solo como parte do sistema de produção agrícola e, numa tentativa de caracterização da carga contaminante lixiviada que se infiltra no subsolo, definir as concentrações a partir da proporção de perdas de peso aplicado.

Atividade mineral - A atividade de extração de minérios mais preocupante, com relação aos recursos hídricos subterrâneos, está associada (a) $\mathrm{NO}_{3} \cdot \mathrm{Ne} \mathrm{Cl}$

- 1+R Immise

\section{(b) PESTICIDA}

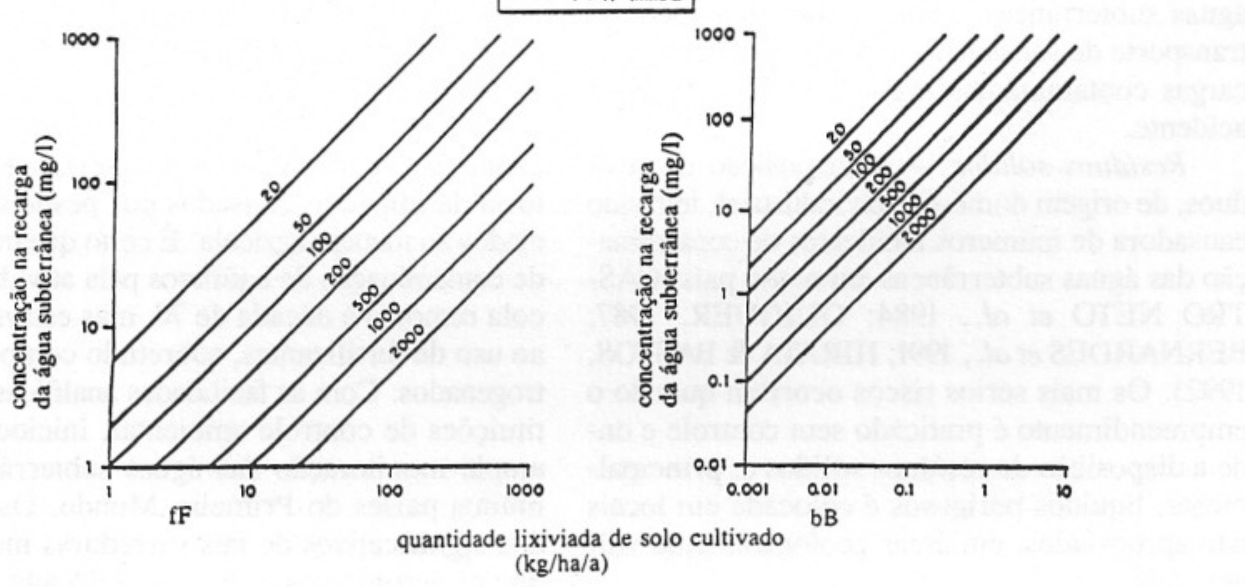

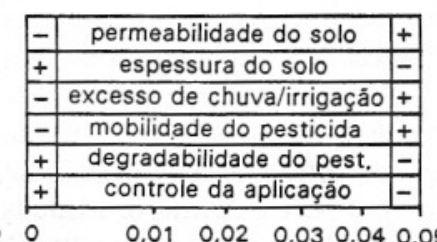

$\begin{array}{llllllllllll}\text { b } & 0 & & 0,01 & 0,02 & 0,03 & 0,04 & 0,05\end{array}$

FIGURA 2 - Estimação de carga contaminante, em zona de recarga sob área de atividade agrícola (FOSTER \& HIRATA, 1989).

aos bens minerais metálicos, à exploração de petróleo e gás e a algumas substâncias não-metálicas muito solúveis. Estes materiais representam perigo para os aqüíferos devido às suas características químicas inerentes (solubilidade e toxicidade) ou por estarem associados a processos de beneficiamento que podem gerar resíduos sólidos, líquidos e gasosos, que apresentam mobilidade em subsuperfície e toxicidade às águas subterrâneas.

Quando o bem mineral explorado não está incluído neste grupo de substâncias, impactos causados sobre as águas subterrâneas poderão ocorrer devido a perturbações hidráulicas, diretas ou indiretas; disposição de líquidos com alto conteúdo salino; e lixiviação do material estéril. Quando campos de petróleo e jazidas de bens minerais estão localizados sob aqüíferos importan- tes, deve ser requerido um cuidado especial durante a construção de obras de acesso à mina ou dos poços de petróleo.

Os bens minerais não-metálicos, de emprego imediato na construção civil, apresentam baixo potencial gerador de cargas contaminantes, uma vez que manuseiam substâncias não-perigosas e muitas vezes inertes. O risco maior está associado à remoção do solo e da camada nãosaturada, expondo muitas vezes o nível freático, reduzindo a capacidade de degradação dos contaminantes no perfil geológico e aumentando a vulnerabilidade do aqüífero. A geração de contaminantes, muitas vezes, poderá estar associada ao sistema de saneamento de funcionários, geralmente por fossas sépticas ou negras, aos pátios das oficinas mecânicas e ao armazenamento de combustíveis e óleos. 


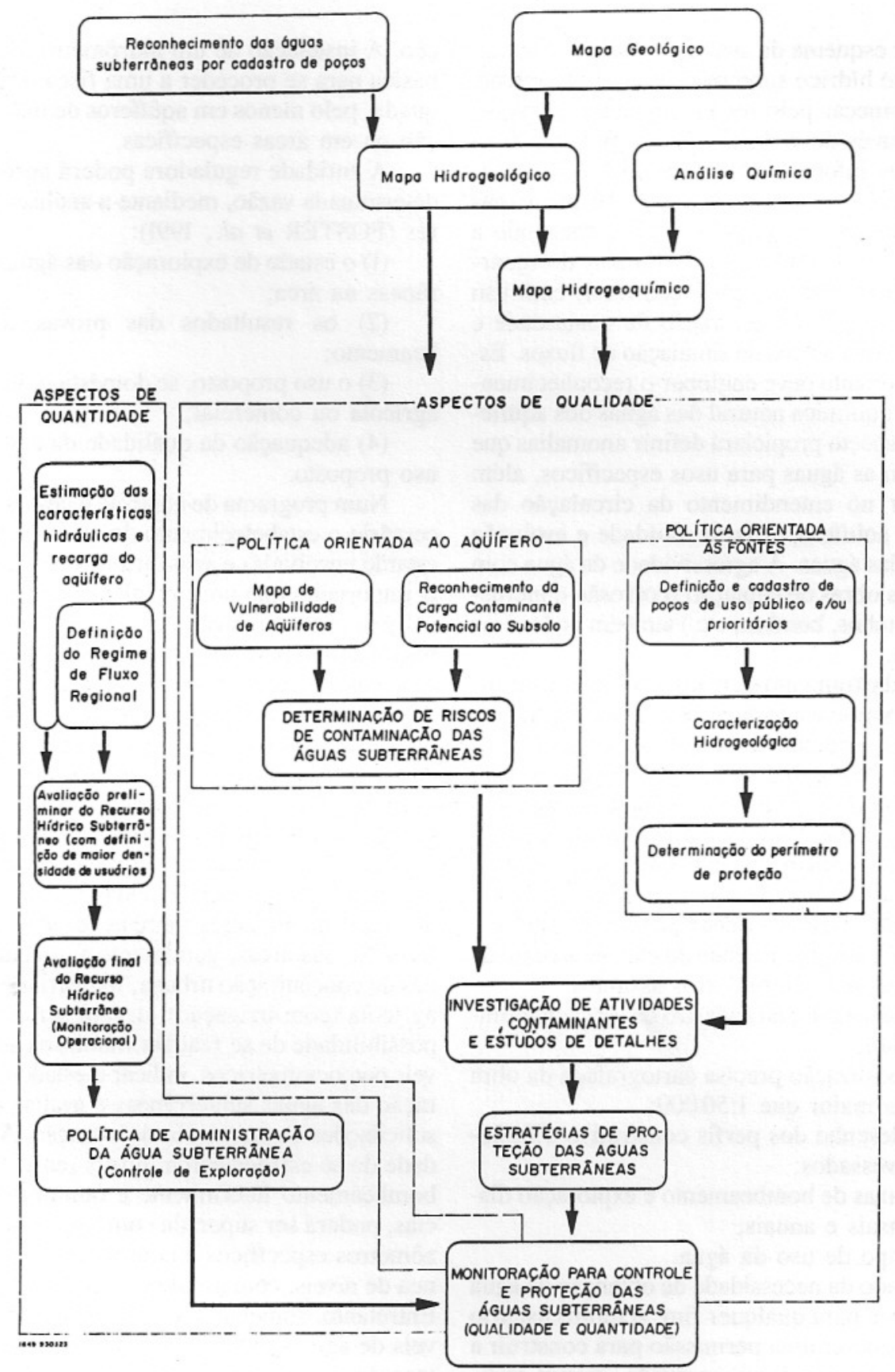

FIGURA 3 - Esquema integrado de gestão dos recursos hídricos subterrâneos, em aspectos de qualidade e quantidade (FOSTER \& HIRATA, 1989).

\section{ESTRATÉGIAS DE PROTEÇÃO DAS ÁGUAS SUBTERRÂNEAS}

\subsection{Aspectos da gestão de quantidade}

Gerir o recurso hídrico subterrâneo em aspectos de quantidade está em manter ou propiciar um abastecimento sustentado da água para um ou mais usos, o que se associa à tríade: existência do recurso-conhecimento adequado-exploração racional. Entretanto, verifica-se que o usuário, pú- blico ou privado, limita-se a saber da existência das águas subterrâneas numa determinada área, pela simples perfuração de poços. A subseqüente diminuição da vazão dos poços é atribuída a causas não-conhecidas ou ao próprio envelhecimento da obra. A solução encontrada por muitos reside na perfuração de outras captações, sem entender que o problema está, muitas vezes, nas limitações do aqüífero ou na sua má exploração.

Um programa de gestão da quantidade das águas subterrâneas é representado na figura 3 . 
Qualquer esquema de avaliação e administração do recurso hídrico subterrâneo necessariamente deverá começar pelo reconhecimento dos aqüíferos, através do cadastro de poços já perfurados. Essas informações, associadas ao mapeamento geológico, permitirão construir mapas hidrogeológicos regionais e locais, chegando a estabelecer uma avaliação preliminar do recurso. Isso permitirá sua avaliação final, com uso de programas de monitoração de quantidade e modelos matemáticos de simulação de fluxos. Este procedimento deve englobar o reconhecimento da hidroquímica natural das águas dos aqüíferos. Tal aspecto propiciará definir anomalias que restrinjam as águas para usos específicos, além de ajudar no entendimento da circulação das águas no aqüífero, a partir da idade e evolução química das águas. A agressividade da água com relação às obras de captação (corrosão e incrustação em tubos, bombas, etc.) também poderá ser detectada.

O cadastramento de poços tubulares e outras obras importantes de captação das águas subterrâneas, em funcionamento e abandonados, é fundamental. Normalmente, a situação que se tem verificado no Brasil é a inexistência de informações específicas. Um primeiro intento no país foi. tomado pelo Estado de São Paulo, com a decretação da Lei Estadual de Águas Subterrâneas (Lei n? 6.134/88 e Decreto-Lei n? 32.955/91), que dispõe sobre a obrigatoriedade do cadastramento de poços tubulares, entre outros assuntos.

Nesse sentido, tal cadastro deverá conter minimamente:

(1) localização precisa cartografada da obra em escala maior que 1:50.000;

(2) desenho dos perfis construtivo e litológico atravessados;

(3) taxas de bombeamento e exploração diárias, mensais e anuais;

(4) tipo de uso da água.

Quando da necessidade de obtenção de água subterrânea para qualquer fim, o futuro usuário deverá requerer uma permissão para construir a obra de captação. Caso aprovada, deverá apresentar um anteprojeto da obra, acompanhado de estudo hidrogeológico adequado. Algumas vezes, o usuário poderá apresentar, em um só momento, o pedido acompanhado de estudo hidrogeológico e anteprojeto da obra.

Após a perfuração do poço, deverá ser apresentado um relatório final, em que constem as principais informações do poço e do aqüífero. Uma permissão de extração deverá ser concedida, quando de uso público, ou autorizada, quando para outros usos, a todos os solicitantes, excluindo-se os de pequena vazão. Mesmo nesses casos seria interessante o cadastro da obra, para se ter conhecimento da existência da capta- ção. A instalação de um hidrômetro é condição básica para se proceder a uma fiscalização adequada, pelo menos em aqüíferos de maior extração ou em áreas específicas.

A entidade reguladora poderá aprovar uma determinada vazão, mediante a análise dos fatores (FOSTER et al., 1991):

(1) o estado de exploração das águas subterrâneas na área;

(2) os resultados das provas de bombeamento;

(3) o uso proposto, se doméstico, industrial, agrícola ou comercial;

(4) adequação da qualidade da água para o uso proposto.

Num programa de controle e gestão será necessário o estabelecimento de quais instituições estarão envolvidas e suas atribuições específicas. É importante que um organismo seja responsável pela administração das águas subterrâneas, respondendo pela aprovação da perfuração e exploração do recurso, bem como da fiscalização da extração e da interação com as águas superficiais. Seria preferível que tal organismo respondesse também pelas águas superficiais, gerindo integralmente o recurso hídrico, e tivesse uma organização por bacias hidrográficas.

Em áreas de intensa extração de água subterrânea, deverão ser adotadas medidas para a avaliação de impactos sobre as reservas do aqüífero. Nessas áreas, geralmente associadas a zonas de concentração urbana, industrial ou de uso agrícola (com irrigação), deverá ser estudada a possibilidade de se realizar monitoração dos níveis potenciométricos, indicar o estado de exploração das águas subterrâneas e avaliar as novas solicitações de permissão de extração. A dificuldade de se estabelecerem níveis reais, frente ao bombeamento intermitente e outras interferências, poderá ser superada com uso de poços piezômetros específicos e com monitoração contínua de níveis, com uso de limnógrafos de poços. Entretanto, somente o acompanhamento dos níveis de água subterrânea e análise de hidrogramas das águas superficiais em bacias específicas, ao longo de vários anos, acompanhados de dados climáticos, permitirão o estabelecimento seguro de recarga do aqüífero. Assim poderá ser assumida a proposição de uma política confiável de extração do recurso hídrico subterrâneo, definindo as vazões máximas explotáveis. Frente à dificuldade no estabelecimento dos balanços hídricos, uma posição realista seria de não impor sérias restrições iniciais, antes de uma avaliação conclusiva da situação de reservas explotáveis.

Coordenadas pela agência gestora do recurso hídrico, ou por um organismo interinstitucional, quando for o caso, deverão ser estabelecidas metas plurianuais dos avanços do conhecimento dos 
aqüíferos e dos programas de proteção e controle. Os objetivos propostos poderão ser definidos conjuntamente com os responsáveis pelo recurso hídrico superficial, de forma integrada.

\section{ASPECTOS DA GESTÃO DE QUALIDADE}

A quase irreversibilidade da degradação química de aqüíferos, somada aos elevados custos do tratamento de águas poluídas, à dificuldade operativa e à demora no estabelecimento de diagnósticos precisos da contaminação das águas subterrâneas, faz com que estabelecer programas de proteção do recurso hídrico subterrâneo, frente a problemas de contaminação, seja uma obrigação dos órgãos gestores do recurso, co-participada pelos usuários estatais e particulares.

Uma análise dos programas de proteção das águas subterrâneas em vários países tem mostrado duas linhas básicas de conduta: uma primeira voltada ao poço de captação, estabelecendo ao redor da obra perímetros de proteção, definidos a partir do tempo de trânsito específico; e uma segunda, mais abrangente, voltada ao aqüífero, onde são estabelecidas restrições ao uso da terra frente à vulnerabilidade do aqǘfero e à importância do recurso como fonte de abastecimento.

\subsection{Estratégia voltada ao aqüífero}

O conceito de vulnerabilidade de um aqüífero é assumido por vários autores como a susceptibilidade do corpo hídrico subterrâneo a ser contaminado por um evento antrópico qualquer. $\mathrm{O}$ termo contaminação é aqui usado como sinônimo de poluição, e entendido como uma alteração na qualidade das águas subterrâneas que exceda os limites aceitáveis para o uso, de um parâmetro específico, estabelecidos por instituições competentes.

A vulnerabilidade do aqüífero é uma função primária da:

(1) acessibilidade hidráulica de contaminantes à sua zona saturada;

(2) capacidade de atenuação (filtração, diluição, sorção, degradação, precipitação, etc.) dos estratos sotopostos à zona saturada.

A essas características da vulnerabilidade do aqüífero, interagem outras, associadas à carga contaminante, que seriam:

(1) o modo de disposição dos contaminantes no solo, particularmente a magnitude da sua carga hidráulica;

(2) o tipo de contaminante, em termos da persistência e mobilidade.

A interação desses fatores determinará o tempo de residência do contaminante em subsuperfície e a demora na chegada à zona saturada, além da intensidade da carga, resultado dos processos de retenção e eliminação.
Alguns autores, analisando a especificidade dos contaminantes e suas relações com o meio, defendem que seria pouco científico considerar a existência de um mapa universal de vulnerabilidade, ou seja, que servisse a todos os tipos de contaminantes e formas de disposição. Esses autores acreditam que seria mais prudente a definição de cartogramas específicos para cada contaminante, grupos de contaminantes (i.e. nutrientes, patógenos, metais pesados, solventes sintéticos, etc.), ou atividades antrópicas (i.e. saneamento in situ, atividade agrícola, disposição de efluentes industriais, etc.) (SELLER \& CANTER, 1980; LE GRAND, 1983; CANTER et al., 1987). No limite, seria necessário, então, estabelecer uma série de mapas, que deveriam ser reunidos em um atlas.

Entretanto, a não existência de informações suficientes e/ou dados adequados impõe sérias limitações a esse procedimento. Como conseqüência, o estabelecimento de sistemas mais generalizados e menos refinados do mapeamento de vulnerabilidade parece ser a alternativa seguida por alguns autores (ALBINET \& MARGAT, 1970; HAERTLE, 1983; ALLER et al., 1985; FOSTER \& HIRATA, 1988).

Os componentes de vulnerabilidade do aqüífero não são diretamente mensuráveis e, sim, determinados por meio da combinação de outros fatores. A redução e simplificação da lista de parâmetros é quase inevitável, caso se pretenda desenvolver um esquema prático de avaliação de risco de contaminação das águas subterrâneas. Em último caso seria possível reduzi-la aos seguintes fatores:

(1) tipo de ocorrência das águas subterrâneas, ou condição do aqüífero;

(2) característica dos estratos que capeiam a zona saturada, nos aspectos litológicos e de condutividade hidráulica;

(3) profundidade do nível d'água;

(4) direção do fluxo das águas subterrâneas.

A partir desses fatores, é possível a definição de mapas de vulnerabilidade. Considera-se, adicionalmente, que essas cartas, apenas com um índice de vulnerabilidade, seriam muito úteis no planejamento de uso dos terrenos e nos programas de proteção das águas subterrâneas, uma vez que permitiriam distinguir áreas com diferentes nuanças de fragilidade. Além do mais, sua validade técnica pode ser assegurada a partir do momento em que suas limitações com relação aos contaminantes móveis e muito persistentes sejam levadas em conta. Estes mapas de vulnerabilidade de forma alguma poderão substituir estudos de detalhe necessários quando da instalação de empreendimentos específicos.

São apresentadas, no quadro 3, várias técnicas para a cartografia de vulnerabilidade de 
QUADRO 3 - PRINCIPAIS MÉTODOS PARA A DEFINIÇÃO DO RISCO E VULNERABILIDADE DAS ÁGUAS SUBTERRÂNEAS À CONTAMINAÇÃO ANTRÓPICA

\begin{tabular}{|c|c|c|c|c|c|c|c|}
\hline MÉTODO & AVALIAÇÃO DE & TIPO & $\begin{array}{l}\text { SIMPL } \\
\text { OPERAT. }\end{array}$ & $\begin{array}{l}\text { OBTENÇ. } \\
\text { DADOS }\end{array}$ & ÍNDICE & FATORES & $\begin{array}{l}\text { REFERÊNCIA } \\
\text { BIBLIOGRAF. }\end{array}$ \\
\hline $\begin{array}{l}\text { LANDFILL SITE RANTING } \\
\text { (Método Le Grand-Brown) }\end{array}$ & $\begin{array}{l}\text { aterros sanitários novos } \\
\text { e em operação }\end{array}$ & $\mathrm{R}$ & C & A & $\begin{array}{l}\text { alfanumérico, uma parte } \\
\text { por soma algébrica e } \\
\text { outra por junção de } \\
\text { letras/índices }\end{array}$ & $\begin{array}{l}\text { distância aterro e poços } \\
\text { produtores } \\
\text { - profundidade nível de água } \\
\text { gradiente do aqüífero } \\
\text { - permeabilidade e capacidade } \\
\text { atenuação }\end{array}$ & $\begin{array}{l}\text { LE GRAND } \\
\text { (1964) }\end{array}$ \\
\hline SITE RANTING SYSTEM & $\begin{array}{l}\text { disposição de produtos } \\
\text { químicos, novos e em } \\
\text { operação }\end{array}$ & $\mathrm{R}$ & C & A & $\begin{array}{l}\text { numérico (0-129), soma } \\
\text { algébrica }\end{array}$ & $\begin{array}{l}\text { solo caract. hidráulicas e de } \\
\text { sorção e tamponamento químico } \\
\text {. hidrodinâmica do aqǘfero } \\
\text {. ar } \\
\text {. população próxima }\end{array}$ & $\begin{array}{l}\text { HAGERTY } \\
\text { et al. } \\
\text { (1973) }\end{array}$ \\
\hline $\begin{array}{l}\text { WASTE-SOIL-SITE } \\
\text { INTERACTION MATRIX }\end{array}$ & $\begin{array}{l}\text { disposição resíduos } \\
\text { sólidos e líquidos e } \\
\text { novas indústrias }\end{array}$ & $\mathrm{R}$ & $\mathrm{C}$ & A & $\begin{array}{l}\text { numérico ( } 45 \text { a } 4.830) \text {, } \\
\text { multiplicação numa } \\
\text { matriz e soma de pontos }\end{array}$ & $\begin{array}{l}\text { - efeitos na saúde } \\
\text { caracter. produto químico } \\
\text { comportamento do produto } \\
\text { químico } \\
\text { capacidade do solo/atenuação } \\
\text { - hidrogeologia } \\
\text { características do local }\end{array}$ & $\begin{array}{l}\text { PHILIPS } \\
\text { et al. } \\
\text { (1977) }\end{array}$ \\
\hline $\begin{array}{c}\text { SITE RANTING } \\
\text { METHODOLOGY (SRM) }\end{array}$ & $\begin{array}{l}\text { disposição resíduos } \\
\text { sólidos e líquidos e } \\
\text { novas indústrias }\end{array}$ & $\mathrm{R}$ & M & M & $\begin{array}{l}\text { numérico (0-100), soma } \\
\text { algébrica }\end{array}$ & $\begin{array}{l}\text { receptor-população/uso da } \\
\text { água/uso local/degradação } \\
\text { ambiental } \\
\text { caminhos-nível e tipo de } \\
\text { contaminação profund. n. água, } \\
\text { pluviometria, permeab. do solo } \\
\text { caract. do resíduo-toxicidade, } \\
\text { persistência } \\
\text { prática de manejo-aspectos } \\
\text { operacionais e construtivos }\end{array}$ & $\begin{array}{l}\text { KULFS } \\
\text { et al. } \\
(1980)\end{array}$ \\
\hline
\end{tabular}




\begin{tabular}{|c|c|c|c|c|c|c|c|}
\hline MÉTODO & AVALIAÇÃO DE & TIPO & $\begin{array}{l}\text { SIMPL } \\
\text { OPERAT. }\end{array}$ & $\begin{array}{l}\text { OBTENÇ. } \\
\text { DADOS }\end{array}$ & ÍNDICE & FATORES & $\begin{array}{l}\text { REFERÊNCIA } \\
\text { BIBLIOGRAF. }\end{array}$ \\
\hline $\begin{array}{l}\text { HAZARD RANKING } \\
\text { SYSTEM }\end{array}$ & $\begin{array}{l}\text { áreas prioritárias para } \\
\text { ação de limpeza do } \\
\text { aqüífero }\end{array}$ & $\mathrm{R}$ & $\mathrm{C}$ & A & $\begin{array}{l}\mathrm{S}=1 / 9,73\left[\mathrm{Sq}_{\mathrm{m}}^{2} \mathrm{w}+\right. \\
\left.\mathrm{Ss}^{2} \mathrm{w}+\mathrm{Sa}^{2}\right]^{1 / 2} \\
\mathrm{Sgw}=\text { água subterrânea } \\
\mathrm{Ssw}=\text { água superficial } \\
\mathrm{Sa}=\text { ar }\end{array}$ & $\begin{array}{l}\text { migração - caract. do meio e } \\
\text { resíduo } \\
\text { - quant. produtos perigosos } \\
\text { - prox. de população humana } \\
\text {. explosão e fogo } \\
\text {. contato direto }\end{array}$ & $\begin{array}{l}\text { CALDWELL } \\
\text { et al. } \\
\text { (1981) }\end{array}$ \\
\hline PESTICIDE INDEX & pesticidas uso normal & $\mathrm{R}$ & M & B & qualitativo & $\begin{array}{l}\text { caract. físico-química do pesticida } \\
\text { - climatologia } \\
\text { - perfil do solo } \\
\text {. cultura }\end{array}$ & $\begin{array}{l}\text { RAD } \\
\text { et al. } \\
\text { (1985) }\end{array}$ \\
\hline DRASTIC & vulnerabilidade geral & V & M & M & $\begin{array}{l}\text { numérico, soma pon- } \\
\text { derada }\end{array}$ & $\begin{array}{l}\text { D profundidade água subterrânea } \\
\text {. } \mathrm{A} \text { recarga } \\
\text { A meio aquífero } \\
\text { S solo } \\
\text { T topografia } \\
\text {. I impacto } \\
\text { C condutividade hidráulica }\end{array}$ & $\begin{array}{l}\text { ALLER } \\
(1985)\end{array}$ \\
\hline GOD & $\begin{array}{l}\text { vulnerabilidade geral } \\
\text { análise e classificação } \\
\text { carga contaminante }\end{array}$ & $\mathrm{V}+\mathrm{C}$ & $\mathrm{S}$ & B & $\begin{array}{l}\text { numérico, multiplicação } \\
\text { simples fatores quali- } \\
\text { tativos }\end{array}$ & $\begin{array}{l}\text {. G tipo ocorrência águas subter- } \\
\text { râneas } \\
\text {. O litologia zona não-saturada } \\
\text { D profundidade da água sub- } \\
\text { terrânea }\end{array}$ & $\begin{array}{l}\text { FOSTER \& } \\
\text { HIRATA } \\
(1988)\end{array}$ \\
\hline $\begin{array}{c}\text { GROUNDWATER } \\
\text { VULNERABILITY MAP } \\
\text { FOR NITRATE }\end{array}$ & $\begin{array}{l}\text { potencial lixiviação } \\
\text { nitrato }\end{array}$ & V & $\mathrm{S}$ & B & $\begin{array}{l}\text { qualitativo com matriz } \\
\text { de cruzamento único }\end{array}$ & $\begin{array}{l}\text { tipo de solo } \\
\text { caract. hidrául. e litol. do } \\
\text { aqǘf́ero }\end{array}$ & $\begin{array}{l}\text { PALMER } \\
\quad(1988)\end{array}$ \\
\hline
\end{tabular}

$\mathrm{S}-$ simples; $\mathrm{M}$ - moderado; $\mathrm{C}-$ complexo $\mathrm{B}$ - baixa dificuldade; $\mathrm{M}$ - média; $\mathrm{A}$ - alta
$\mathrm{R}$ - vulnerabilidade e carga incorporada num índice $\mathrm{V}$ - mapeamento vulnerabilidade C - carga contaminante em separado 


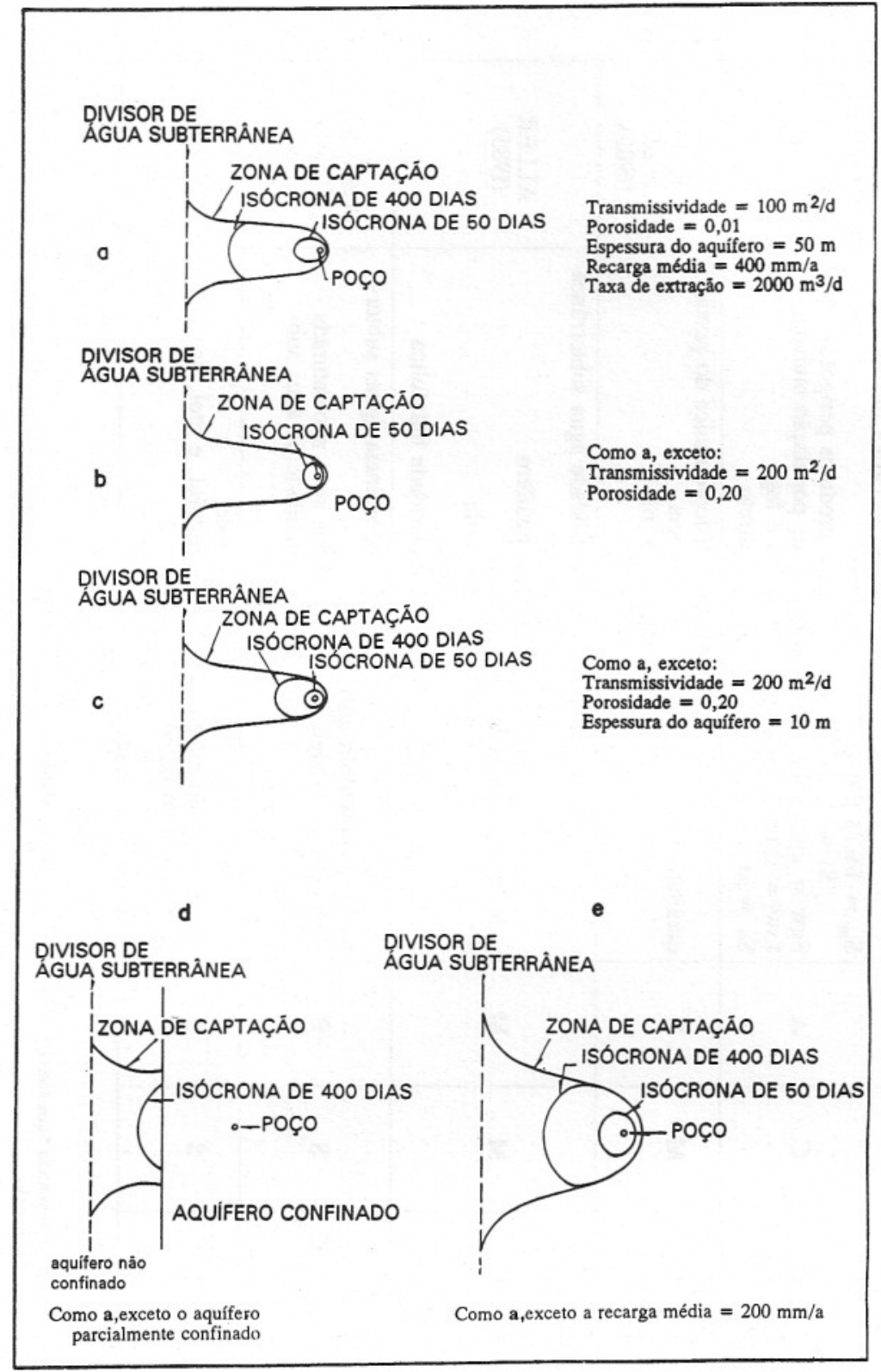

FIGURA 4 - Perímetro de proteção de poços (PPP), em aqüíferos homogêneos e isotrópicos, com distintas características hidráulicas.

aqüíferos, bem como as informações mínimas necessárias para suas definições.

\subsection{Estratégias voltadas à obra de captação}

Com o objetivo de estabelecer a proteção das águas subterrâneas associada a poços de exploração que possuam importância, quer para o abastecimento público ou outros usos, alguns países utilizam como estratégia a definição de perímetros em torno do poço. Estes são traçados a partir da velocidade do fluxo das águas na zona saturada. Os perímetros de proteção de poços (PPP), associados ao uso restritivo do solo para atividades potencialmente contaminantes, permitem uma defesa do aqüífero (FIGURA 4).
Segundo USEPA (1987), a adoção do programa de PPP, a partir de 1989, nos Estados Unidos, objetivou estabelecer uma zona contígua ao poço que:

(1) permitisse aos órgãos de controle ambiental ações de remediação no caso de uma contaminação inesperada do aqüífero;

(2) provesse a captação de uma zona de atenuação, que funcionaria, a partir das características hidráulicas e físico-químicas do aqüífero, como redutor da carga contaminante, antes de sua chegada ao poço;

(3) estabelecesse uma zona de manejo, para o controle de atividades na área de recarga do aqüífero. 
Na Europa, o uso de PPP é mais antigo e se estende a diversos países. Dadas as especificidades sócio-econômicas e legislativas, existe uma dificuldade na comparação desses perímetros.

De uma forma geral, são definidas quatro grandes zonas de proteção. A primeira é associada à área do próprio poço $(15 \mathrm{a} 30 \mathrm{~m})$, onde geralmente são permitidas apenas atividades inerentes à extração de água que, em muitos casos, é cercada. A segunda zona é estabelecida para a proteção contra organismos patogênicos. Normalmente são definidos a partir de tempos de trânsito na zona saturada de 50 a 60 dias (alguns países utilizam de 10 a 400 dias), o que garante, na maioria dos casos, a eliminação completa de grande parte das espécies de bactérias e vírus que poderiam atingir o poço. Nessa zona é proibida qualquer construção e existem sérias restrições de uso agrícola do solo. A terceira zona serve à proteção contra contaminantes mais persistentes. Foi definida a partir da experiência com estudos de caso, onde se verificou que a grande maioria dos incidentes de poluição não ultrapassava dois quilômetros (WAEGENINGH, 1985) (FIGURA 5). Alguns autores defendem que essa zona deveria ser definida, a exemplo das outras, com base nos tempos de trânsito, e propõem que seja maior que a segunda zona, sobrepassando 500 dias. Associam-se-lhes restrições, tais como a construção de certas indústrias, armazenamento e transporte de certos compostos químicos. A quarta zona normalmente é definida como a área de recarga do aqüífero, ou parte dela, entretanto não sendo menor que $25 \%$ de sua área de afloramento.

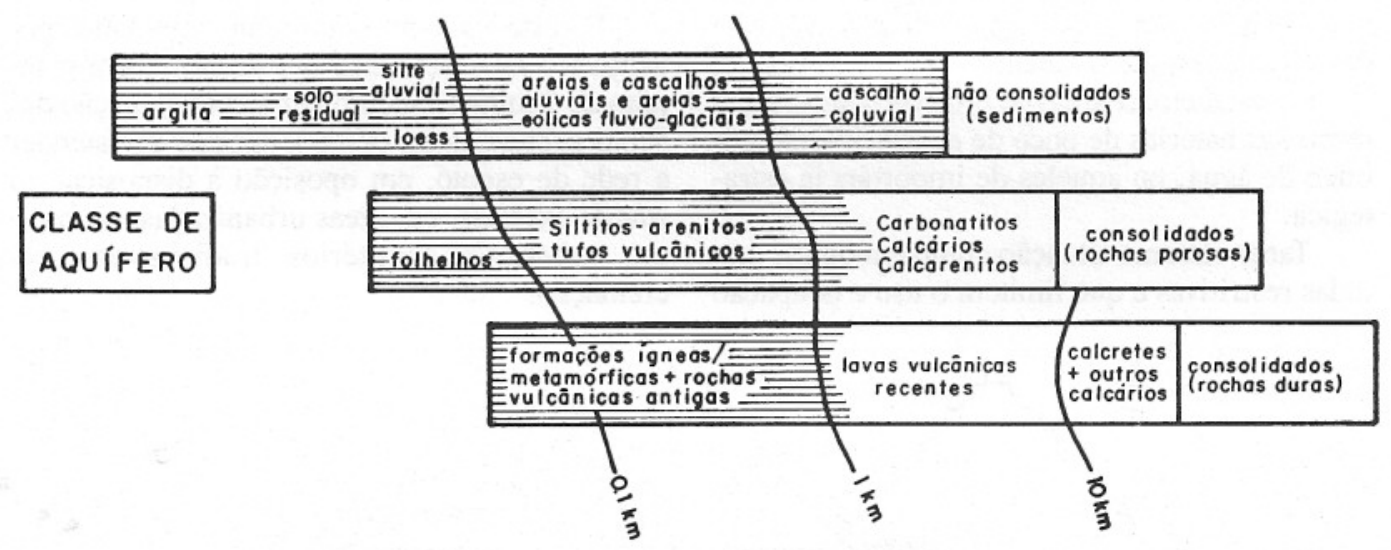

FIGURA 5 - Classificação dos aqüíferos, segundo a propagação da pluma contaminante (FOSTER \& HIRATA, 1988).

Vários modelos matemáticos foram desenvolvidos nos últimos anos para auxiliar no traçado dos PPP, entre os quais podem ser citados: o FLOWPATH, da Waterloo Software; o HWPA, da Hydrologic Inc. (1990); o RESSQ, da Lawrence, Bekeley Laboratories (1985); e o GWPATH, da Shafer Associates (1990).

\subsection{Manejo da qualidade do aqüífero}

Tanto a estratégia voltada aos poços de captação, através de PPP, como a que considera a vulnerabilidade de aqüíferos, apresentam restrições. A definição de perímetros de proteção, mesmo com as facilidades de modelos de simulação, esbarra nas seguintes dificuldades (FOSTER et al., 1988):

(1) número crescente de poços em muitas áreas torna inviável o estabelecimento de zonas de proteção fixas;
(2) deficiências de dados e incertezas técnicas dificultam o cálculo das dimensões requeridas pelos PPP, exigindo um trabalho de detalhe, caso a caso, normalmente oneroso (FIGURA 6);

(3) enfoque do perímetro de proteção está centrado no tempo de trânsito na zona saturada, quando, na prática, é a zona não-saturada a que oferece a barreira mais eficaz contra a contaminação.

Da mesma forma algumas considerações podem ser estabelecidas com relação ao método de vulnerabilidade, que seriam:

(1) restrição quanto à aplicabilidade e validade técnico-científica de mapas de vulnerabilidade de caráter geral quando aplicados a quaisquer classes de contaminantes e distintas formas de disposição no solo;

(2) impossibilidade ou extrema dificuldade na criação de atlas de mapas de vulnerabilidade específicos. Pela dificuldade na obtenção de infor- 
mações e sua carência, é também bastante restritiva a espacialização dos dados pontuais, restringindo a confiança existente nos traçados dos limites entre diferentes unidades de vulnerabilidade.

(3) aplicabilidade de mapas de vulnerabilidade, que se restringe apenas a situações de pequena escala. A nível de detalhe ( $>1: 10.000$ ), que, pela necessidade de maior grau de informação, poderia alimentar modelos de simulação de transporte de massa, com muito maior eficiência nas predições.

(4) dificuldade em remover, ou mesmo restringir, a instalação das atividades potencialmente contaminantes em uma área de alta vulnerabilidade.

Em vista destas dificuldades, a atitude mais realista e prática na conservação da qualidade das águas subterrâneas é buscar a combinação das duas opções, por meio das seguintes diretrizes:

(1) exceder a proteção geral do aqïfero, sobretudo na área de recarga, com medida de controle das atividades que o afetem;

(2) estabelecer áreas de proteção especial em torno das baterias de poço de abastecimento público de água, ou aqueles de importância estratégica.

Tanto em uma situação como em outra, medidas restritivas e que limitem o uso e ocupação do solo para algumas atividades deverão ser tomadas. No caso das áreas de PPP, o quadro 4 apresenta um resumo das atividades permitidas, controladas e proibidas em cada uma das quatro zonas de proteção. Da mesma forma, um quadro de aceitabilidade é proposto para diferentes zonas de vulnerabilidade do aqüífero. É certo que tais recomendações não deverão ser tomadas inflexivelmente e cada caso deverá ser analisado frente à importância e demanda atual e futura do aqüífero, para diversos usos. É necessária também a compatibilização do recurso hídrico subterrâneo com outras formas de suprimento de água.

A exemplo da legislação paulista, todo empreendimento que pode causar grande impacto às águas subterrâneas, em aspectos quantitativos e qualitativos, somente será aprovado após estudos detalhados. Os relatórios de impacto sobre o meio ambiente (EIA/RIMA) deverão contemplar as águas subterrâneas.

É certo também que muitas atividades poderão ter seus desenhos otimizados, com o intuito de diminuir ou eliminar a contaminação das águas subterrâneas, como a decisão de estender a rede de esgoto, em oposição à disposição in situ de excretas, em áreas urbanizadas; ou mesmo substituir cemitérios tradicionais pela cremação.
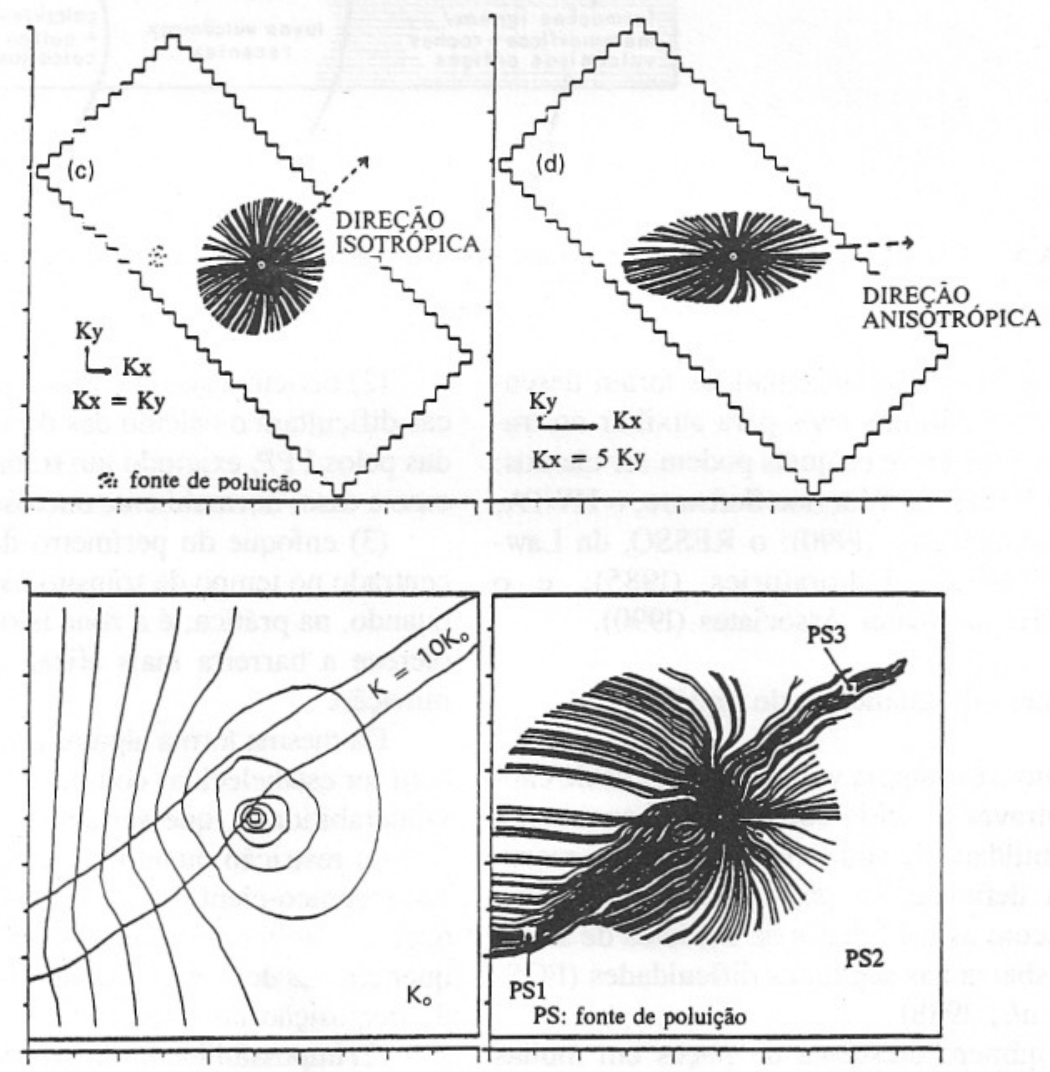

FIGURA 6 - Efeitos da anisotropia em aqüíferos na definição de perímetro de proteção de poços (CLEARY \& CLEARY, 1991). O índice K significa condutividade hidráulica da rocha. 
QUADRO 4 - PRINCIPAIS ATIVIDADES PERMITIDAS E PROIBIDAS EM CADA UMA DAS ÂREAS DOS PERÍMETROS DE PROTEÇÃO DE POÇOS E EM RELAÇÃO AOS ÍNDICES DE VULNERABILIDADE DE AQÜÍFEROS (BASEADO EM FOSTER et al., 1991; ADAMS, 1991; NATIONAL RIVERS AUTHORITY, 1991; SELBY \& SKINNER, 1978; SOUTHER WATER AUTHORITY, 1985)

\begin{tabular}{|c|c|c|c|c|c|c|c|}
\hline \multirow{2}{*}{$\begin{array}{l}\text { Atividade potencialmente contaminante } \\
\text { Contaminante }\end{array}$} & \multicolumn{4}{|c|}{ Perímetro proteção de poço } & \multicolumn{3}{|c|}{ Vulnerabilidade natural } \\
\hline & I & II & III & IV & Alta & Média & Baixa \\
\hline $\begin{array}{l}\text { Saneamento in situ } \\
\text {. unifamiliar } \\
\text {. edifícios, coletivos, públicos }\end{array}$ & $\begin{array}{l}\mathrm{N} \\
\mathrm{N}\end{array}$ & $\begin{array}{l}\mathrm{N} \\
\mathrm{N}\end{array}$ & $\begin{array}{c}\mathrm{A} \\
\mathrm{PA}\end{array}$ & $\begin{array}{l}\mathrm{A} \\
\mathrm{A}\end{array}$ & $\begin{array}{l}\text { A } \\
\text { A }\end{array}$ & $\begin{array}{l}\mathrm{A} \\
\mathrm{A}\end{array}$ & $\begin{array}{l}\mathrm{A} \\
\mathrm{A}\end{array}$ \\
\hline $\begin{array}{l}\text { Postos de gasolina } \\
\text { Aeroportos }\end{array}$ & $\mathrm{N}$ & $\mathrm{N}$ & PN & $\mathrm{PA}$ & $\mathrm{PA}$ & A & A \\
\hline $\begin{array}{l}\text { Disposição de resíduos sólidos } \\
\text {. doméstico municipal } \\
\text {. mat. construção (inerte) } \\
\text {. resíduos perigosos } \\
\text {. industrial (Classe I) } \\
\text {. industrial (Classe II e III) } \\
\text {. cemitérios } \\
\text {. incinerador de resíduos perigosos }\end{array}$ & $\begin{array}{l}\mathrm{N} \\
\mathrm{N} \\
\mathrm{N} \\
\mathrm{N} \\
\mathrm{N} \\
\mathrm{N} \\
\mathrm{N}\end{array}$ & $\begin{array}{l}\mathrm{N} \\
\mathrm{N} \\
\mathrm{N} \\
\mathrm{N} \\
\mathrm{N} \\
\mathrm{N} \\
\mathrm{N}\end{array}$ & $\begin{array}{c}\mathrm{N} \\
\mathrm{PA} \\
\mathrm{N} \\
\mathrm{N} \\
\mathrm{N} \\
\mathrm{PN} \\
\mathrm{N}\end{array}$ & $\begin{array}{l}\text { PN } \\
\text { PA } \\
\text { N } \\
\text { PN } \\
\text { N } \\
\text { A } \\
\text { PN }\end{array}$ & $\begin{array}{l}\text { PN } \\
\text { A } \\
\text { N } \\
\text { PN } \\
\text { N } \\
\text { PA } \\
\text { N }\end{array}$ & $\begin{array}{l}\mathrm{PA} \\
\mathrm{A} \\
\mathrm{N} \\
\mathrm{PA} \\
\mathrm{N} \\
\mathrm{A} \\
\mathrm{PN}\end{array}$ & $\begin{array}{l}\text { A } \\
\text { A } \\
\text { PA } \\
\text { A } \\
\text { PA } \\
\text { A } \\
\text { PA }\end{array}$ \\
\hline $\begin{array}{l}\text { Minerações } \\
\text { material construção } \\
\text { outros minérios, incluindo petróleo e gás } \\
\text {. linhas de combustíveis }\end{array}$ & $\begin{array}{l}\mathrm{N} \\
\mathrm{N} \\
\mathrm{N}\end{array}$ & $\begin{array}{l}\mathrm{N} \\
\mathrm{N} \\
\mathrm{N}\end{array}$ & $\begin{array}{l}\mathrm{PN} \\
\mathrm{N} \\
\mathrm{N}\end{array}$ & $\begin{array}{l}\mathrm{PA} \\
\mathrm{N} \\
\mathrm{PN}\end{array}$ & $\begin{array}{l}\mathrm{PA} \\
\mathrm{N} \\
\mathrm{N}\end{array}$ & $\begin{array}{l}\text { PA } \\
\text { PA } \\
\text { PA }\end{array}$ & $\begin{array}{l}\text { A } \\
\text { A } \\
\text { A }\end{array}$ \\
\hline $\begin{array}{l}\text { Indústrias } \\
\text {. classe I } \\
\text { classe II e III } \\
\text {. instalações militares }\end{array}$ & $\begin{array}{l}\mathrm{N} \\
\mathrm{N} \\
\mathrm{N}\end{array}$ & $\begin{array}{l}\mathrm{N} \\
\mathrm{N} \\
\mathrm{N}\end{array}$ & $\begin{array}{c}\text { PN } \\
N \\
N\end{array}$ & $\begin{array}{l}\mathrm{PA} \\
\mathrm{N} \\
\mathrm{N}\end{array}$ & $\begin{array}{l}\mathrm{PA} \\
\mathrm{PN} / \mathrm{N} \\
\mathrm{PN}\end{array}$ & $\begin{array}{l}\mathrm{PA} \\
\mathrm{PA} / \mathrm{N} \\
\mathrm{PA}\end{array}$ & $\begin{array}{c}\mathrm{A} \\
\mathrm{PA} / \mathrm{PN} \\
\mathrm{PA}\end{array}$ \\
\hline $\begin{array}{l}\text { Lagoas de efluentes } \\
\text {. municipal } \\
\text {. água resfriamento } \\
\text {. industrial }\end{array}$ & $\begin{array}{l}\mathrm{N} \\
\mathrm{N} \\
\mathrm{N}\end{array}$ & $\begin{array}{l}\mathrm{N} \\
\mathrm{N} \\
\mathrm{N}\end{array}$ & $\begin{array}{l}\mathrm{N} \\
\mathrm{PA} \\
\mathrm{N}\end{array}$ & $\begin{array}{c}\mathrm{PN} \\
\mathrm{A} \\
\mathrm{N}\end{array}$ & $\begin{array}{c}\text { PN } \\
\text { A } \\
\text { PN }\end{array}$ & $\begin{array}{l}\text { A } \\
\text { A } \\
\text { PA }\end{array}$ & $\begin{array}{l}\text { A } \\
\text { A } \\
\text { PA }\end{array}$ \\
\hline $\begin{array}{l}\text { Drenagem/infiltração/acidentes } \\
\text {. águas pluviais (tetos) } \\
\text {. estradas principais } \\
\text {. estradas secundárias } \\
\text {. áreas de recreação } \\
\text {. garagens e estacionamentos } \\
\text {. áreas industriais } \\
\text { linhhas férreas } \\
\text {. aeroportos }\end{array}$ & $\begin{array}{l}P A \\
N \\
N \\
N \\
N \\
N \\
N \\
N\end{array}$ & $\begin{array}{l}\text { A } \\
\text { N } \\
\text { PN } \\
\text { PA } \\
\text { N } \\
\text { N } \\
\text { N } \\
\text { N }\end{array}$ & $\begin{array}{l}\text { A } \\
\text { N } \\
\text { PA } \\
\text { PA } \\
\text { PN } \\
\text { N } \\
\text { N } \\
\text { N }\end{array}$ & $\begin{array}{l}\text { A } \\
\text { PN } \\
\text { PA } \\
\text { A } \\
\text { PA } \\
\text { PN } \\
\text { PN } \\
\text { PN }\end{array}$ & $\begin{array}{c}\text { A } \\
\text { PN } \\
\text { PA } \\
\text { A } \\
\text { PA } \\
\text { PN* } \\
\text { PN } \\
\text { PN }\end{array}$ & $\begin{array}{l}\text { A } \\
\text { PA } \\
\text { A } \\
\text { A } \\
\text { A } \\
\text { PA } \\
\text { PA } \\
\text { PA }\end{array}$ & $\begin{array}{l}\text { A } \\
\text { A } \\
\text { A } \\
\text { A } \\
\text { A } \\
\text { A } \\
\text { A } \\
\text { A }\end{array}$ \\
\hline $\begin{array}{l}\text { Infiltração efluentes no solo } \\
\text {. indústria alimentícia } \\
\text {. outras indústrias } \\
\text {. efluentes de deságüe } \\
\text {. lodo de deságüe } \\
\text {. escorrimento de currais }\end{array}$ & $\begin{array}{l}\mathrm{N} \\
\mathrm{N} \\
\mathrm{N} \\
\mathrm{N} \\
\mathrm{N}\end{array}$ & $\begin{array}{l}\mathrm{N} \\
\mathrm{N} \\
\mathrm{N} \\
\mathrm{N} \\
\mathrm{N}\end{array}$ & $\begin{array}{l}\text { PN } \\
\text { N } \\
\text { N } \\
\text { PN } \\
\text { PN }\end{array}$ & $\begin{array}{l}\text { PA } \\
\text { N } \\
\text { PN } \\
\text { PA } \\
\text { A }\end{array}$ & $\begin{array}{l}\text { PA } \\
\text { PU } \\
\text { PA } \\
\text { PA } \\
\text { A }\end{array}$ & $\begin{array}{l}\text { A } \\
\text { PA } \\
\text { A } \\
\text { A } \\
\text { A }\end{array}$ & $\begin{array}{l}\text { A } \\
\text { A } \\
\text { A } \\
\text { A } \\
\text { A }\end{array}$ \\
\hline $\begin{array}{l}\text { Gado intensivo } \\
\text {. efluentes em lagoas } \\
\text {. deságüe de currais }\end{array}$ & $\begin{array}{l}\mathrm{N} \\
\mathrm{N}\end{array}$ & $\begin{array}{l}\mathrm{N} \\
\mathrm{N}\end{array}$ & $\begin{array}{c}\mathrm{N} \\
\mathrm{PN}\end{array}$ & $\begin{array}{l}\text { PN } \\
\text { PA }\end{array}$ & $\begin{array}{l}\text { PA } \\
\text { PA }\end{array}$ & $\begin{array}{l}\mathrm{A} \\
\mathrm{A}\end{array}$ & $\begin{array}{l}\mathrm{A} \\
\mathrm{A}\end{array}$ \\
\hline $\begin{array}{l}\text { Atividade Agrícola } \\
\text {. uso de pesticidas } \\
\text { uso não controlado de fertilizante ou dis- } \\
\text { posição aberta } \\
\text {. armazenamento pesticidas }\end{array}$ & $\begin{array}{l}\mathrm{N} \\
\mathrm{N} \\
\mathrm{N}\end{array}$ & $\begin{array}{l}\mathrm{N} \\
\mathrm{N} \\
\mathrm{N}\end{array}$ & $\begin{array}{l}\text { PN } \\
\text { N } \\
\text { PN }\end{array}$ & $\begin{array}{l}\text { A } \\
\text { PN } \\
\text { PA }\end{array}$ & $\begin{array}{l}\text { PN } \\
\text { PN } \\
\text { PN }\end{array}$ & $\begin{array}{l}\text { A } \\
\text { A } \\
\text { PA }\end{array}$ & $\begin{array}{l}\text { A } \\
\text { A } \\
\text { A }\end{array}$ \\
\hline
\end{tabular}

$\mathrm{N}$ não aceitável em virtualmente todos os casos

PN provavelmente não aceitável, exceto em alguns casos com estudo detalhado

PA provavelmente aceitável, com estudo e projeto especial

A aceitável, com projetos especiais

*PA, com conecções à rede interceptora

I perímetro imediato de proteção

II perímetro bacteriológico

III perímetro de produtos químicos

IV área de recarga do aqüífero 
Em casos restritos, é aceitável a contaminação do aqüífero, exigindo-se o tratamento de suas águas. Tal opção é razoável, apenas após estudos de viabilidade econômica de outras fontes alternativas ou mesmo da limpeza do aqüífero. Em última instância deverá ser aceita uma das alternativas:

(1) aceitação da contaminação do aqüífero, buscando fontes alternativas e garantindo a não propagação da(s) pluma(s) de contaminação;

(2) tratamento das águas do aqüífero, após sua extração;

(3) eliminação da fonte de contaminação e limpeza do aqǘf́ero e do solo.

$\mathrm{O}$ mapeamento de vulnerabilidade, conjuntamente analisado com a carga contaminante potencial, fornecerá instrumento importante na definição de políticas de proteção da qualidade das águas, na medida que estabelece áreas de maior risco ambiental. Nestas áreas, prioritariamente, deverão ser implantados programas de monitoração da qualidade das águas subterrâneas e estudos de detalhe, em caso de confirmação da contaminação.

\section{A HIDROGEOLOGIA AMBIENTAL: AS ÁGUAS SUBTERRÂNEAS NO PLANEJAMENTO DE USO E OCUPAÇÃO DO SOLO}

\subsection{As Geociências e o planejamento ambiental}

O estudo da questão ambiental envolve ou se serve de várias áreas de conhecimento, onde se distinguem, dentro da ciência geológica, as disciplinas de caráter básico, das aplicadas. Para o planejamento físico-territorial, que objetiva, em última análise, a manutenção da qualidade de vida, os mapeamentos geológico e o geomorfológico se destacam como disciplinas básicas. Entre as áreas aplicadas, quatro ganham importância: geotecnia, hidrogeologia, recursos minerais e monumentos geológicos. Esta última, tendo como campo o resgate e preservação de sítios e materiais geológicos de interesse ao conhecimento ou à didática. Não obstante, qualquer estudo de planejamento de uso e ocupação do solo necessariamente deverá utilizar-se de outras disciplinas não-geológicas.

\subsection{Aspectos hidrogeológicos considerados}

A hidrogeologia para o planejamento urbano deverá responder às seguintes necessidades básicas: a demanda quantitativa; a adequação composicional, em aspectos físicos, químicos e bacteriológicos; a degradação da qualidade das águas do aqüífero por intervenção antrópica; a influência da hidráulica subterrânea no compor- tamento geotécnico; e as capacidades energéticas do recurso hídrico subterrâneo.

Quanto à demanda quantitativa, devem ser respondidas as questões: 1) Qual a vazão que poderá ser extraída com a perfuração de um poço neste local? 2) Qual o melhor projeto para extrair esta vazão? ou, ainda, 3) Até quando a exploração deste poço, em conjunto com os demais, poderá ser mantida neste ritmo sem esgotar o aqǘfero?

A adequação composicional refere-se à hidrogeoquímica do aqüífero. Neste aspecto deverão ser solucionados os seguintes pontos: 1) $\mathrm{A}$ qualidade natural da água é adequada ao uso proposto, inclusive como água mineral? 2) Qual o perfil construtivo mais adequado frente à composição físico-química das águas do aqüífero?

Dizem respeito à questão da contaminação de aqüíferos as seguintes indagações: 1) A atividade que será instalada, ou está em operação, contaminará o aqüífero? ou 2) O solo poderá assimilar uma carga contaminante intencional disposta num dado local?

As características geotécnicas referem-se às questões: 1) A exploração deste poço, ou desta bateria de poços, poderá causar problemas de fundação em obras civis ou estruturais do terreno? 2) Quais efeitos a hidráulica do terreno (níveis de saturação, p.ex.) poderá causar na estabilidade de um determinado maciço?

$\mathrm{E}$, finalmente, os aspectos energéticos estarão associados à pergunta: 1) As características térmicas do aqüífero poderão ser aproveitadas para geração de energia ou ter uso recreativo?

Quando o geoambientalista estiver analisando uma área para um dado empreendimento ou mesmo avaliando as conseqüências de uma ocupação passada, deverá contemplar estes cinco aspectos. A resposta às questões estará vinculada a um bom entendimento da geometria e hidráulica do aqüífero, das relações rocha-água em subsuperfície e de substâncias alóctones com o meio. Devem-se considerar, particularmente, os seguintes fatores:

(1) composição litológica e estratigrafia regional e do local estudado, incluindo análise das estruturas deformacionais. Isto permite a definição do modelo de circulação das águas subterrâneas, estabelecendo áreas de recarga, de descarga e de trânsito do(s) aqüífero(s), tempo de circulação das águas e possíveis relações com outras unidades hidrogeológicas;

(2) disponibilidade qualitativa, como fonte de água potável ou outros usos, a partir do conhecimento da condutividade hidráulica dos estratos rochosos e coeficientes de armazenamento, bem como suas variações espaciais;

(3) relação entre águas subterrâneas e águas superficiais, quantificando as infiltrações e des- 
cargas do aqüífero e permitindo estabelecer uma extração racional, com definição das reservas explotáveis;

(4) cadastro do usuário do recurso hídrico subterrâneo, prioritariamente incluindo os maiores consumidores, e de forma complementar os menores. Com isso será possível conhecer a demanda atual, projetá-la e obter dados geológicos e hidráulicos do aqüífero (através de informações de testes de bombeamento), bem como aspectos construtivos dos poços;

(5) composição química da água subterrânea, analisando a adequabilidade ao uso e às características que permitam aproveitá-la como bem mineral. Uma interpretação hidrogeológica de dados químicos auxiliará no entendimento da circulação das águas e em alguns casos, devido à má qualidade, permitirá excluir alguns aqüíferos para estudos detalhados em sua utilização como fonte de água potável, por exemplo;

(6) características que a classifiquem como lazer, como, por exemplo, fontes térmicas para balneários;

(7) grau geotérmico, permitindo seu aproveitamento como fonte de energia;

(8) mineralização das águas, sobretudo quando associada a elevados graus geotérmicos. Em alguns casos, poderá ser utilizada como fonte de um bem mineral específico e que tenha um alto valor agregado;

(9) casos de contaminação das águas subterrâneas e sua vulnerabilidade com relação a ações antrópicas quaisquer. Neste caso deverá ser estabelecido o comportamento de contaminantes específicos, ou grupos de contaminantes, em subsuperfície, quanto à advecção, dispersão, sorção e degradação;

(10) comportamento geotécnico do maciço e do solo, associado à hidráulica subterrânea.

Os resultados destas informações poderão ser obtidos, ou mesmo representados, em documentos e cartografias, tais como:

(1) mapa hidrogeológico, que inclui o tipo e as características hidráulicas dos aqüíferos, modelo de circulação das águas, fluxo e nível piezométrico e a profundidade do nível d'água;

(2) cadastro de poços tubulares e outras captações e seus usuários;

(3) balanço hídrico da bacia;

(4) mapa de zonas de potencialidade similar, que limita áreas com igual rendimento dos poços. Este mapa é elaborado a partir das características hidrológicas e geológicas (de subsuperfície e de superfície), que podem incluir, em casos mais complexos, a análise dos ambientes de sedimentação (IG, 1991; 1992);

(5) mapa hidrogeoquímico (SHENK, 1983);

(6) mapa de vulnerabilidade de aqǘf́reros com relação à contaminação antrópica;
(7) cadastro de fontes potencialmente contaminantes;

(8) algumas vezes, estudos específicos, incluindo testes em laboratório, amostragens e sondagens.

\subsection{Problemas específicos em áreas urbanas:} alguns aspectos metodológicos

Em estudos de planejamento ambiental, em áreas urbanas, a solicitação de definições e respostas precisas aos problemas normalmente apresentados faz necessária a utilização de escalas maiores que 1:50.000 (LEMOS et al., 1990; HIRATA et al., 1991). A densidade de informações requeridas para uma dada escala, no campo das águas subterrâneas, ainda é assunto bastante controverso.

Informações hidrogeológicas são obtidas, na maior parte das vezes, a partir de pontos de água existentes. Poços e outras formas de captação têm distribuição bastante irregular, pois são função da ocupação humana. A perfuração de poços de pesquisa é bastante rara, principalmente em estudos hidrogeológicos básicos, devido obviamente aos elevados custos. Então, em qualquer trabalho onde se utilizam informações existentes haverá áreas onde quase inexistem dados, como o caso de muitos aqüíferos cristalinos (IG, 1990; 1991; 1992).

Comparando-se vários trabalhos de cartografia hidrogeológica, no Brasil e no exterior, conclui-se que a densidade de informações por área não é, na maior parte das vezes, condizente com a escala de representação. CHAPOND \& MORTIER (1967) definem que se deveria trabalhar com densidades de informações iguais às utilizadas em mapeamentos geológicos básicos, ou seja, 0,5 a 1 ponto a cada $4 \mathrm{~cm}^{2}$ de representação cartográfica. Na escala 1:50.000, isto representaria de 0,5 a 1 ponto a cada $\mathrm{km}^{2}$ e nas escalas 1:25.000 e 1:10.000 uma densidade de 2.000 a 4.000 pontos a cada $1.000 \mathrm{~km}^{2}$. Em estudos de poluição de aqüíferos, FOSTER \& HIRATA (1988) estabelecem que, para escalas 1:50.000 a 1:100.000, haveria necessidade de 1 ponto a cada 1 ou $2 \mathrm{~km}$.

Quando se está trabalhando em escalas de semidetalhe é necessária a obtenção de dados de ensaios de bombeamento específicos. Em escalas maiores que 1:50.000, seria importante realizar 5 a 15 ensaios, e em escalas maiores que 1:25.000, 10 a 30 (LLAMAS et al., 1983).

Como em qualquer estudo geológico, a densidade de informações necessárias será uma função da homogeneidade e continuidade das características, bem como da disponibilidade e acesso aos dados, associados ao objetivo do projeto. 
Em estudos de aproveitamento dos recursos hídricos, a densidade de informações hidrogeoquímicas será menor que a utilizada no cadastro de pontos de água e, segundo LLAMAS et al. (1983), deveria cobrir de 20 a $30 \%$ dos poços cadastrados. CHAPOND \& MORTIER (1967) recomendam que somente seja feita uma análise completa em cada quatro realizadas. Nas demais seria necessário apenas medir alguns parâmetros indicativos, tais como condutividade elétrica, concentração de cloretos e dureza.

Algumas vezes, para se identificarem problemas composicionais das águas subterrâneas, que poderiam estar associados à contaminação do aqüífero ou a alguma anomalia hidrogeoquímica, não é necessário realizar análises químicas completas em todas as amostras coletadas. Alguns parâmetros, os chamados indicativos, permitem, através de uma medida indireta, mostrar tais desvios da qualidade da água, não sendo necessário proceder, pelo menos num primeiro momento, a análises laboratoriais de elevado preço. Os baixos custos destes parâmetros permitem que eles sejam repetidos não somente em vários pontos, mas também com maior freqüência temporal.

Os parâmetros indicativos mais comuns são: condutividade elétrica (associada à presença de sais); concentração de cloretos (escolhidos devido à sua alta mobilidade em subsuperfície); presença de bactérias heterotróficas e coliformes fecais e totais (como indicativo de contaminação de origem animal); concentração de carbono orgânico total (COT), inclusive sintéticos; algumas vezes, concentração de nitrogênio (total, amônio, nitrato) e de compostos halogenados (TOX). Os parâmetros indicativos apresentam restrições, como o COT, que possui altos valores de limite de detecção (lmg/l), o que faz com que contaminações importantes de solventes halogenados, em níveis de ug/l, por exemplo, não sejam detectadas. Da mesma forma, coliformes apresentam uma sobrevivência pequena em subsuperfície, se comparados a muitos patógenos, denotando falsos negativos. Os parâmetros indicativos, muitas vezes, só terão significado quando comparados a valores regionais (background) ou a amostras de um mesmo ponto coletadas anteriormente.

Os parâmetros físico-químicos e bacteriológicos das análises completas deverão ser estabelecidos de acordo com o uso que se propõe dar à água. Entretanto, será interessante analisar as amostras, pelo menos ocasionalmente, quanto aos itens incluídos no Decreto Federal no 79.637 (potabilidade, Portaria n. 56, exceto os radioativos, que poderão ser definidos em problemas específicos), que contempla os íons maiores, metais, metais pesados, orgânicos sintéticos, pesticidas, bactérias e características organolépticas. Para uma monitoração preventiva, será importante estabelecer quais destes parâmetros deverão ser analisados rotineiramente e aqueles que servirão como indicativos. Estes itens deverão ser selecionados em função da ocupação do terreno nas proximidades do poço de extração.

$\mathrm{O}$ uso de sondagens geofísicas e de perfuração de poços, necessário quando se está trabalhando em escalas de maior detalhamento, é quase imprescindível em estudos de poluição das águas subterrâneas. Métodos geofísicos mais comuns são a eletrorresistividade (SEV e caminhamento elétrico), o eletromagnetismo (restritivamente a sísmica) e os amostradores de vapores do solo (AVS) (HIRATA et al., 1988; HIRATA, 1991). A perfuração de poços, sendo o investimento mais caro, deverá ser definida, numa segunda etapa, depois de estudos preliminares, da interpretação dos dados existentes, da coleta e análise de pontos de água, dos trabalhos de geofísica e da simulação de modelos matemáticos simples.

Os modelos matemáticos podem ser divididos em dois grandes grupos: os de fluxo, que definem a circulação das águas subterrâneas, e os de transporte de massa, que simulam o movimento de contaminantes em subsuperfície. Os modelos disponíveis comercialmente permitem interpretar tanto testes de bombeamento em aqüíferos livres (GWAP - teoria de Neuman) e confinados (PUMPTEST - Cooper-Jacob), como simulações de circulação das águas subterrâneas associados à extração e recarga (PLASM, FLOWIDI), até definir o tempo em que uma pluma contaminante irá atingir um poço com vazões intermitentes (MOC-USGS, RESSQ). Entretanto, em situações com baixa densidade de informações, os modelos matemáticos são muito práticos para "sentir" as situações e avaliar quantitativamente um caso específico, não se limitando desta forma a ser rodados apenas quando da existência de grande quantidade de dados de campo.

Sendo de fácil manejo, muitos modelos poderão ser utilizados em diferentes fases do estudo, permitindo a otimização e aumentando a segurança de etapas posteriores como, por exemplo, na definição de locais de perfuração de poços de monitoração, na escolha da densidade de pontos de coleta, ou mesmo em situações de complicada hidráulica subterrânea, na definição de direções dos fluxos subterrâneos.

\subsection{Perspectivas}

Nesta década, a Geologia parece estar restrita a pequenos investimentos para a área de pesquisa. Tal cenário está levando muitos técnicos latino-americanos e europeus, particularmente na área de hidrogeologia, a buscarem otimizar seus 
estudos, de forma a obterem resultados baseados, quando possível, em dados existentes. Em países do Terceiro Mundo, a falta e a não-aplicação de políticas claras e legislações adequadas fazem com que muitas informações se percam ou sejam mal aproveitadas. A "reciclagem" de informações parece ser uma prática necessária e adequada, não somente nos momentos de dificuldades econômicas. Entretanto, em outros casos, novos dados deverão ser gerados para suplantar problemas ambientais pouco entendidos, o que representa novos investimentos na área de pesquisa, que deveriam ser direcionados àquelas de maior importância sócio-econômica e ambiental.

No Estado de São Paulo, muitos dados, oriundos de perfurações de poços tubulares, acabam se perdendo pelo não-cumprimento da Lei Estadual de Águas Subterrâneas, que institui o cadastramento da obra, com apresentação de relatório final do poço, com dados da geologia e de hidráulica do aqǘfero. Da mesma forma, informações geradas pelas sondagens SPT não são centralizadas, dificultando e restringindo seu uso à obra a que foi originariamente destinada. Sondagens rasas deste tipo se prestam muito bem à definição do nível do aqüífero freático e do fluxo subterrâneo.

O uso de Sistemas Geográficos de Informação (GIS) parece ser outra nova tendência da geologia ambiental. Este sistema computacional permite o cadastro, a cartografia, o cruzamento e a integração de informações de variados tipos. O GIS otimiza os resultados e faz com que a informação cartográfica possa ser literalmente manuseada dentro de computadores. O GIS é extremamente útil quando se tem que cruzar informações de várias cartas, como ocorre nos mapeamentos temáticos para o planejamento, ou mesmo na construção de mapas de vulnerabilidade. A possibilidade de uso deste sistema, juntamente com dados existentes confiáveis e modelos matemáticos de simulação, potencializaria em muito os resultados que poderiam ser gerados. A implementação de GIS em uma dada instituição exige não somente a aquisição de equipamentos, normalmente caros, mas a formação de equipes permanentes de estudo e para a digitalização da informação gerada.

\section{CONCLUSÕES}

Dois grandes problemas podem ser associados à exploração dos recursos hídricos subterrâneos: a superexploração, que representa a extração de quantidade de água acima dos limites suportáveis do aqüífero, e a contaminação de sua qualidade natural, causada por atividades antrópicas.
A proteção quantitativa do recurso hídrico subterrâneo está em estabelecer duas linhas de ação: uma voltada a poços existentes e outra a futuras obras de captação. No primeiro caso, a partir de um cadastramento dos poços e dos usuários, deverão ser definidas áreas de maior extração do recurso. Nestas, será necessário estabelecer os impactos presentes e futuros sobre o aqüífero, com o estabelecimento de um programa de gerenciamento do recurso, otimizando e racionalizando a exploração. Na segunda linha, todas as obras de captação de águas subterrâneas, a partir de um porte, deverão pedir uma autorização para a sua instalação e operação, baseada em estudos prévios. Em áreas de maior extração de água e/ou de maior importância, deverá ser estabelecida uma rede de monitoração de níveis piezométricos do aqüífero, com avaliação de recargas e interação entre águas superficial e subterrânea.

Para a definição de políticas e programas de prevenção da contaminação das águas subterrâneas, duas estratégias distintas, mas complementares, deverão ser implementadas: uma primeira, que consiste em definir perímetros de proteção das obras de captação e, uma segunda, em que se autorizam diferentes tipos de ocupação do solo, frente à vulnerabilidade do aqüífero. Tanto uma estratégia como a outra apresentam dificuldades para sua implementação, o que faz, na prática, com que a atitude mais realista seja buscar uma combinação das duas opções. Uma legislação condizente com a realidade do local deverá definir que atividades poderão ser instaladas ou melhoradas em cada uma das áreas de proteção.

Cabe à hidrogeologia, como uma disciplina de caráter aplicado, responder às seguintes necessidades: demanda quantitativa, adequação composicional, degradação da qualidade da água, respostas geotécnicas associadas ao comportamento da água no maciço, e capacidades energéticas do recurso hídrico subterrâneo.

Nesta década, os restritos investimentos na área de pesquisa concentram as perspetivas, para a hidrogeologia ambiental, no uso cada vez maior de informações existentes, permitindo a sua otimização; na utilização de modelos matemáticos de simulação devido à sua facilidade e à disponibilidade; e no uso de Sistemas Geográficos de Informação (GIS).

\section{AGRADECIMENTOS}

Gostaria de agradecer à Geól. Amélia João Fernandes, pelas discussões técnicas e revisão dos originais, à Geog. Luciana Martin Ferreira, pela confecção das figuras e à Sandra Moni, pela digitação dos quadros e diagramas. 


\section{REFERÊNCIAS BIBLIOGRÁFICAS}

ADAMS, B. 1992. Comunicação verbal.

ALBINET, M. \& MARGAT, J. 1970. Cartographie de la vulnerabilité a la pollution des nappes d'eau souterraine. Bull BRGM $2 \mathrm{me}$ Series 3(4):13-22.

ALLER, L.; BENNETT, T.; LEHER, J.; PETTY, R. 1985. DRASTIC: a standardized system for evaluating groundwater pollution potential using hydrogeologic setting. USEPA Report 600/2-85/018.

BERNARDES, C.; HIRATA, R.; MENDES, J.; CLEARY, R. 1991. Remedial action for a industrial open dump. Proposed activities and prospectives. Wat.Sci.Tech. (24).

CAMPOS, J. 1988. Indícios de abatimento dos níveis de água subterrânea da bacia sedimentar de São Paulo. In CONG. BRAS. ÁGUAS SUBTERRÂNEAS, 5, São Paulo, 1988, Anais...São Paulo, ABAS, p. 74-83.

CANTER, A.; PALMER, R.; MONKHOUSE, R. 1987. Mapping the vulnerability of groundwater to pollution from agriculture practice particularly in respect of nitrate. In INTER. CONF. VULNERABILITY OF SOIL AND GROUNDWATER TO POLLUTANT, Nordwijk, Proc...Nordwijk, Países Baixos. IHAS.

CASTRO NETO, P.; BARROTTI, A.; BERNARDES, C.; TOSHIMITSO, J. 1984. Aterro sanitário da Cyanamid Química do Brasil Ltda. (fábrica de Resende). In CONG. BRAS. ÁGUAS SUBTERRÂNEAS, 3, Fortaleza, 1984, Anais... Fortaleza, ABAS, p. 144-156

CHAPOND, G. \& MORTIER, F. 1967. Los métodos de estudio y la programacion em hidrogeologia. Instituto Geológico y Minero de España. p. 31-34.

CLEARY, T. \& CLEARY, R. 1991. Delineation of wellhead protection areas: theory and practice. Wat.Sci.Tech. (21):140-151.

FOSTER, S. \& HIRATA, R. 1989. Groundwater pollution risk assessment: a methodology using available data. CEPIS Technical Report: $81 \mathrm{p}$.

FOSTER, S.; HIRATA, R.; ROCHA, G. 1988. Risco de poluição das águas subterrâneas: uma proposta metodológica de avaliação regional. In CONG. BRAS. ÁGUAS SUBTERRÂNEAS, 5, São Paulo, 1988, Anais...São Paulo, ABAS, p. 175-185.
FOSTER, S.; VENTURA, M.; HIRATA, R. 1987. Groundwater pollution: an executive overview of the Latin America-Caribean situation in relation to potable watersupply. CEPIS Technical Report: $38 \mathrm{p}$.

FOSTER, S.; ADAMS, B.; MORALES, M.; TENJO, S. 1991. Groundwater protection policy: a guide to requirements. CEPIS Technical Report: versão preliminar.78 p.

GOWLER, A. 1983. Underground purification capacity. IAHS Publication 142:1063-1072.

GUIGUER, N. 1987. Poluição das águas subterrâneas causadas por aterros sanitários: uma abordagem matemático-experimental. (Dissertação de mestrado, Escola Politécnica - USP, inédita).

HEARTLE, A. 1983. Toxic organic chemicals: destruction and waste treatment. Poll Tech Review. 40:317 p.

HIRATA, R. \& BASTOS, C. (coords). 1992. Mapa de vulnerabilidade e risco de poluição das águas subterrâneas do Estado de São Paulo. Relatório Final, IG, CETESB, DAEE, EMBRAPA. São Paulo, 4v.

HIRATA, R. \& CLEARY, R. 1991. The use of soil-gas sampling in the study of groundwater pollution by volatile solvents (VOC): the exemple of Porto Feliz case. Water Sci.Tech. (24):205-216.

HIRATA, R. \& FERREIRA, L. 1992. Poluição das águas subterrâneas por indústrias: um método de avaliação de riscos. In CONG. HIDROGEOLOGICO LATINO-AMERICANO, 1, Merida, Venezuela, 1992, Anais...Merida, ALSHUD.

HIRATA, R. 1991. Amostradores de vapores de solo (AVS): o desenvolvimento de uma técnica para a detecção de água subterrânea contaminada por solventes orgânicos voláteis. Estudo de caso. Porto Feliz (SP). (Dissertação de Mestrado, Instituto de Geociências. USP, Inédito).

; CLEARY, R.; BASTOS, C. 1988. Amostragem de gases na zona vadosa: uma nova técnica para o estudo da contaminação das águas subterrâneas por solventes voláteis. In CONG. BRAS. AGUAS SUBTERRÂNEAS， 5, São Paulo, 1988, Anais...São Paulo, ABAS, p. 196-206.

HIRATA, R.; FERNANDES, A.; YOSHINAGA, S.; PRESSINOTTI, M.; NOGUEIRA, S.; LEMOS, A. 1991. Aplicação e discussão do 
método de unidades homogêneas para o planejamento territorial. Estudo de caso de Itu (SP). In SIMP. GEOL. SUDESTE, 2, São Paulo, Atas...São Paulo, SGB-Núcleo SP. 337-344.

IG - INSTITUTO GEOLÓGICO. 1990. Subsidios do meio físico-geológico para o planejamento territorial do município de Sorocaba. Relatório Final IG/SMA.3v.

1991. Subsídios do meio físico-geológico para o planejamento territorial do $\mathrm{mu}$ nicípio de Itu. Relatório Final IG/SMA.3v.

1992. Subsídios do meio físico-geológico para o planejamento territorial do município de Campinas. Relatório Final IG/SMA.3v.

LE GRAND, H. 1983. A standardized system for evaluating waste disposal sites. NWWA, Worthington, $\mathrm{OH}$ : $49 \mathrm{p}$.

LEMOS, A; SANTORO, J; SOARES, P; HIRATA, R. 1990. Subsídios do meio físicogeológico ao planejamento territorial: a experiência do IG no município de Sorocaba (SP). In CONG. BRAS. GEOL, 32, Natal, 1990. Anais... Natal. SBG. v.2.

LLAMAS, R.; DAVIS, S.; GALOFRÉ, A.; CUSTODIO, E. Exploración de aguas subterráneas. 1983. In CUSTODIO, E. \& LLAMAS, R. 1991. Hidrologia subterránea. Ed Omega. Cap. 15.

MENEZES, A. \& ARAUJO, R. 1988. Causas da salinização dos poços da praia de Abreulândia em Fortaleza (CE). In CONG. BRAS. ÁGUAS SUBTERRÂNEAS, 5, São Paulo, 1988, Anais...São Paulo, ABAS, p. $165-174$.

MONTENEGRO, A.; RIGHETTO, A. 1990. Modelação matemática do manancial subterrâneo de Ribeirão Preto (SP) 3. Simulações computacionais. In CONG. BRAS. ÁGUAS SUBTERRÂNEAS, 6, Porto Alegre, 1990, Anais...Porto Alegre, ABAS, p. 117-124.
NATIONAL RIVERS AUTHORITY. 1991. Policy and practice for the protection of groundwater. Relatório para consulta. 45 p.

REBOUÇAS, A. \& MENEZES, M. 1988. Groundwater a vital resource in Brazil. In INTER. GEOL. SURVEY CONGRESS, 28, Washington DC, 1988, Proc...Washington.

RITTER, W. 1990. Pesticide contamination of groundwater in the United States - a review. J Environ. Sci. Heath. B25(1), 1-29.

RODRIGUES, G.; PARAIBA, L.; BUSCHINELLI, C. 1992. Análise da carga contaminante por pesticidas e nitrato para as águas subterrâneas no Estado de São Paulo. (Inédito).

SCHENK, V. 1983. Hydrochemical maps as basic information for the protection of groundwater. GROUND WATER IN WATER RESOURCES PLANNING. UNESCO, vol. 2.

SELBY, K. \& SKINNER, A. 1978. Aquifer protection in the Servern-Trent Region: policy and pratice. Annual Conference, Conf.Paper n.11, Torquay.

SELLER, L. \& CANTER, L. 1980. Summary of selected groundwater quality impact assessment methods NCGWP Report 80-3, Norman OK: 142 p.

SOUTHER WATER AUTHORITY. 1985. Aquifer protection policy. Relatório Técnico. $47 \mathrm{p}$.

USEPA. 1987. Guidelines for delineation of well head protection areas. USEPA 440/ 6-87-010.

WAEGENINGH, H. 1985. Protection of groundwater quality in porous permeable rocks. In MATHESS, G.; FOSTER, S.; SKINNER, A. 1985. Theoretical background, hydrogeology and practice of groundwater protection zones. IAH-HEISE. vol. 6.

Endereço do autor:

Ricardo Aoki Hirata - Instituto Geológico - SMA - Av. Miguel Estéfano, 3900 - 04301-903 - São Paulo, SP - Brasil. 